\title{
ALTERNATIVES
}

Turkish Journal of International Relations

Volume 1 Number 1 Spring 2002

\section{TRANSITIONAL STRATEGIES AND THE INCLUSIVE DEMOCRACY PROJECT}

\section{Takis Fotopoulos*}

The collapse of actually existing socialism and the parallel failure of Western social democracy and its replacement by today's neoliberal consensus in combination with the rise of the ideology of postmodernism ${ }^{1}$ and the decline of antisystemic movements ${ }^{2}$ have inevitably led to a corresponding decline of a discussion which was still flourishing a few decades ago: the discussion on a transitional strategy towards an alternative society. This was inevitable, because the abandonment by the Left (Old, New, and Green) of any vision for an alternative society in effect made such strategies redundant. A basic criterion which we may use in distinguishing between the various transitional strategies which have been proposed in the past and the few being proposed today is whether a strategy aims at reforming the present institutions without proposing any alternative institutional framework, or whether, instead, it aims at replacing the present society's institutional framework, that is, the system of the globalised market economy and the complementary institution of representative 'democracy', as well as the corresponding system of values that constitutes the dominant social paradigm on which the present society is based. On the basis of this criterion we may distinguish between 'non-systemic' and 'anti-systemic' strategies.

Thus, 'non-systemic' are all those approaches which aim at reforming the present institutional framework and system of values through a variety of tactics ranging from the conquest of state power to pressures 'from below'. Here, we may classify the old socialdemocratic strategy and the new reformist strategies proposed by supporters of the civil societarian and radical democracy approaches, as well as by most supporters of the 'new' social movements and postmodern politics (Green, feminist, 'identity' movements and so on) .

'Antisystemic' are all those approaches which explicitly or implicitly challenge the legitimacy of the socio-economic 'system', both in the sense of its institutions, which create and reproduce the unequal distribution of power (considered here as the ultimate cause of antisystemic social divisions ${ }^{3}$ ), and also in the sense of its values, which legitimise the domination of a human being over human being, or of Society over Nature. Here, we may classify the old statist socialist and libertarian socialist strategies, as well as 
the more recent guerrilla strategy, the libertarian municipalism strategy and, finally, the inclusive democracy strategy.

An intermediate position between the nonsystemic and antisystemic strategies is occupied by the 'direct action' and what we may call 'lifestyle strategies'. Supporters of these strategies sometimes adopt them for overtly reformist aims but there are also cases, particularly in the past, when some of those strategies, like the general strike, were supported as a clearly antisystemic weapon. Today, however, the cases in which 'lifestyle' and 'direct action' strategies are proposed as antisystemic strategies are rare and, even if they are proposed as such, they are not accompanied by a coherent proposal for an alternative institutional framework. It is therefore clear that the 'mixed' nature of lifestyle and direct action strategies rules out the possibility of classifying them either as pure nonsystemic or as antisystemic strategies.

I will consider first the various strategies which have been proposed for the transition to an alternative society (even though reformist strategies do not strictly qualify as transitional strategies) and I will then discuss in more detail the strategy for the transition to a confederal inclusive democracy.

\section{1.'Non-Systemic' (Reformist) strategies}

The reformist strategies aim at bringing about radical social change through either the conquest of state power (reforms 'from above'), or through the creation of autonomous-from-the-state power bases which would press those controlling the political and economic institutions for reforms (reforms 'from below'). 'Radical social change' ranges from a systemic change brought about by gradual change from above, (as was the aim of the socialdemocratic strategy in the past), to a change of the existing institutions through a 'deepening' of democracy or 'socialising' the market economy brought about by pressure 'from below' (civil societarian approach), or finally just a change of some institutions and values not involving a 'universalist' political project for systemic change (postmodern politics, 'new' social movements etc).

\section{The socialdemocratic strategy of reforms 'from above'}

For Bernstein, the father of revisionism and social democracy, the strategy was in fact identical to the content of the socialist project itself. Thus, the socialdemocratic strategy aimed at the conquest of state power with the strategic goal of a gradual socialisation of the existing political institutions and property, rather than the replacement of representative 'democracy' and the market economy with new institutions securing the equal distribution of political and economic power. Thus, as Kolakowski points out: ${ }^{4}$ 
The essential question (for Bernstein) was not whether to accept or reject revolutionary violence but whether processes of socialisation within the capitalist economy were 'already' part of the building of socialism...The movement towards socialism was not the prelude to a great expropriation but simply meant more collectivisation, more democracy, equality and welfare - a gradual trend with no predetermined limit and, by the same token, no 'ultimate goal'.

Social democracy reached its peak during the period of statism and particularly in the first thirty years after WWII, when not only socialdemocratic parties took over power in many Western countries (Britain, Germany, France, Italy etc) but also a program based on a 'social democratic consensus' was dominant all over the Western world'. However, the internationalisation of the market economy since the mid ' 70 s brought about the end of this consensus and the rise of the neoliberal consensus, (i.e. neoliberal modernity) - which, in my view, ${ }^{6}$ is irreversible as long as the market economy is internationalised, in other words, as long as the market economy reproduces itself. The recent deletion from the program of the British Labour Party (which was the last socialdemocratic party still committed to socialisation of the means of production) of 'clause four', which committed it to full socialisation, marked the formal end of socialdemocratic claims towards real systemic change. In fact, the neoliberal agenda for 'flexible' labour markets, minimisation of social controls on markets, replacement of the welfare state by a safety net etc has now become the agenda of every major socialdemocratic party in power or in opposition. The parallel degradation of social democracy and the reversal of most of its conquests (comprehensive welfare state, state commitment to full employment, significant improvement in the distribution of income) has clearly shown that supporters of the revolutionary approach were always right on the impossibility of bringing about a systemic change through reforms.

This is particularly so today when reforms also have to be compatible with the requirements of the internationalised market economy. It is therefore clear that as long as the system of the market economy and representative 'democracy' reproduces itself, all that reforms ('from above', or 'from below') can achieve today is temporary victories, i.e. social conquests which would be as reversible as those achieved during the period of the social democratic consensus, which are now being systematically dismantled by neoliberals and social-liberals alike. ${ }^{7}$ This is because the growth (and therefore the profitability) of Transnational Corporations (TNCs) depends on the continuous expansion of world markets. This means that a market economy today can only be an internationalised one -something that implies that markets have to be as open and as flexible as possible. So, globalisation and its main effects, i.e. the present concentration of power and the continuous worsening of the ecological crisis, will persist for as long as the present institutional framework --that secures the concentration of political and economic power-- reproduces itself, in other words, for as long as the market economy system and representative 'democracy' are not replaced by an institutional framework securing the 
equal distribution of political and economic power among all citizens, i.e. an inclusive democracy.

Similar arguments apply to the 'reformism-as-a-strategy' approach, which is usually used by Trotskyites of various sorts but is also supported today by 'libertarians' like Michael Albert of Znetwork. This strategy represents the old Marxist strategy of pressing for reformist demands in the expectation that the elites will be unable to meet them, so that the ensuing crisis would set in motion a dynamics that will lead to the radicalisation of consciousness and, possibly, to a 'revolutionary situation'. Although, theoretically, this is an anti-systemic approach, in practice it ends up as a reformist trend something that it is indicated, also, by the fact that supporters of this trend deliberately pursue a strategy of alliances with supporters of pure reformist trends (social democrat trade unionists, NGOs, environmentalists etc). Obviously, such 'unholy alliances' are feasible exactly because supporters of this trend do not propose any anti-systemic political project but restrict themselves to purely reformist demands. No wonder therefore that Alex Callinicos, the theoretical guru of the British Socialist Workers Party, sees in Pierre Bourdieu the intellectual who represents the emerging international Left, and himself proposes 'an international economic regulation which would control capitalism...a reform of capitalist globalisation'! ${ }^{8}$

However, the potential of this strategy to radicalise consciousness and bring about a liberatory society has already been shown in History when similar strategies had invariably led to a reformist mentality and reforms which were easily reversible. This was the case in West Europe, where the bulk of the labour movement, as a result of such strategies, developed a reformist mentality, whilst the old socialdemocratic parties were converted into today's social-liberal parties which preside over the building of the neoliberal form of modernity. ${ }^{9}$ This is the inevitable outcome of the fact that a strategy based on reformist demands is, by its nature, incapable of creating a mass anti-systemic consciousness, let alone a really democratic one that can only be created within a long process of 'democracy in action', which would eventually lead to an inclusive democracy. The fact that statists of all persuasions, particularly Marxist-Leninists and Trotskyites, prefer this strategy is not of course surprising in view of their adoption of a 'scientific' view of the liberatory project, and of the related Leninist principle of 'consciousness from without' -a principle which leads directly to Stalinism.

\section{The civil societarian strategy of reforms 'from below'}

This approach, which can hardly be called a strategy as it does not call for the replacement of the present political and economic institutions, involves the enhancement of 'civil society', that is, strengthening the various networks which are autonomous from state control (unions, churches, civic movements, co-operatives, neighbourhoods, schools of thought etc.) in order to impose effective limits (i.e. social controls) on markets and the 
state. However, this strategy is based on a number of unrealistic assumptions. Thus, first, it implicitly assumes a high degree of statism where the state can still play the economic role it used to play during the socialdemocratic consensus. Second, it assumes, in effect, an almost closed market economy where the state and corporations can ignore the degree of competition prevailing in an internationalised market economy, as a result of the free markets for commodities and particularly for capital, which can move instantly across frontiers in case serious social controls are implemented to meet the demands of civil societarians. No wonder that civil societarians usually deny (or try to minimise) the importance of the present internationalisation of the market economy. ${ }^{10}$ It is also indicative that when civil societarians attempt to internationalise their approach the only limits on the internationalised market economy that they view as feasible are various 'regulatory controls'. However, such controls have very little in common with the sweeping social controls that they propose when they discuss, (abstracting from the reality of the present internationalised market economy), the limits that civil society networks should impose on markets (drastic reduction of inequalities, massive creation of jobs etc).

It is therefore clear that the civil societarian strategy is both athistorical and utopian. It is a-historical, since it ignores the structural changes, which have led to the present neoliberal consensus and the internationalised market economy. And it is utopian because it is in tension with both the present internationalised market economy and the state. So, given that civil societarians do not see the outcome of this inevitable tension in terms of the replacement of the market economy and the state by the civil society, it is not difficult to predict that any enhancement of the civil society will have to be compatible with the process of further internationalisation of the market economy and the implied role of the state. THerefore, the 'enhancement' of civil society, under today's conditions, would simply mean that the ruling political and economic elites will be left undisturbed to continue dominating society, while, from time to time, they will have to try to address the demands of the civil societarians-- provided, of course that these demands are not in direct conflict with their own interests and the demands of oligopolistic competition.

In conclusion, enhancing the civil society institutions has no chance whatsoever of either putting an end to the concentration of power, or of transcending the present multidimensional crisis. This conclusion may be derived from the fact that the implicit, and sometimes explicit, aim of civil societarians is to improve the functioning of existing institutions (state, parties, market), in order to make them more responsive to pressures from below when, in fact, the crisis is founded on the institutions themselves and not on their malfunctioning! But, in the present internationalised market, the need to minimise the socio-economic role of the state is no longer a matter of choice for those controlling production. It is a necessary condition for survival. This is particularly so for European capital that has to compete with capital blocks, which operate from bases where the socialdemocratic tradition of statism was never strong (the United States, the Far East). But, even at the planetary level, one could seriously doubt whether it is still possible to enhance the institutions of civil society within the context of the market economy. Granted that the fundamental aims of production in a market economy are individual gain, economic 
efficiency and growth, any attempt to reconcile these aims with an effective 'social control' by the civil society is bound to fail since, as historic experience with the statist phase has shown, social control and market efficiency are irreconcilable objectives. ${ }^{11}$ By the same token, one could reasonably argue that a basic contradiction of the market economy today is the one arising from the fact that any effective control of the ecological implications of growth is incompatible with the requirements of competitiveness, which the present phase of the marketisation process imposes.

Still, the reformist civil societarian strategy, although clearly incapable of bringing about any radical changes in the present institutional structures, is popular even among many anti-globalisation activists, particularly NGOs, Greens and others. However, such activities have no chance whatsoever of functioning as catalysts for systemic change, or even as elements of a transitional strategy for the same purpose. This is not only because the actions of anti-globalisers cannot hope to achieve anything more than a few reversible reforms but also because such actions, by themselves, are hardly useful in the creation of an anti-systemic consciousness . Particularly so, if they do not constitute an integral part of a programmatic mass political movement for systemic change.

In this context, one should not forget the parameters set by the institutional framework. Given that the neoliberal consensus and the present form of globalisation are not just policy changes, as most in the Left assume, but structural changes imposed by the internationalisation of the market economy, one may hypothesise that the basic elements of neoliberal globalisation and particularly the crucial elements of ope $n$ and flexible markets will never go away as long as the market economy is reproduced. open and as flexible as possible. Therefore, an internationalised market economy can only produce an internationalised civil society in which, eventually, social controls over markets would have been universalised but, at the same time, minimised.

\section{Postmodern politics of reform}

There are several types of strategies proposed by postmodernists, although the term 'strategy', again, is hardly relevant here as all postmodern movements are clearly reformist today aiming at reforming the present institutional framework rather than at replacing it with alternative forms of social organization. Thus, despite the clear universal character of the present institutional framework, no postmodern social movement today challenges the main political and economic institutions which constitute its universality: the system of the market economy and representative 'democracy'. Instead, a basic axiom of all social movements influenced by postmodern ideas is their anti-universalism, which by definition excludes such movements from any form of antisystemic politics. ${ }^{12}$

The two main types of postmodern strategies are, first, the 'alliance politics' and second the 'radical democracy' politics. Both these types of postmodern politics have as 
their main point of reference the 'identity movements' (feminist, black, gay etc), as well as the Green movement.

The identity movements are in fact the outgrowth of the 'new' social movements which reached their peak in the 1970s and have started to decline since the mid-1980s, when they began to be involved in what has been called "identity politics," i.e. the kind of postmodern politics which implies a turn away from general social, political, and economic issues toward concerns with culture and identity. The conversion of potentially antisystemic movements into reformist ones was particularly striking with respect to the feminist and the Green movements. Although both started out as radical modern movements with 'universalist' demands to change society as the only way to abolish the domination of man over woman and nature, the rise of neoliberal globalisation, i.e. of the neoliberal form of modernity, created the conditions for the conservative currents within these movements to become dominant and convert them into today's fragmented 'identity' reformist movements.

The dominant trends within the Green movement today do not challenge the fundamental institutions of the market economy and representative 'democracy' but, instead, either adopt a mix of the reformist socialdemocratic and civil societarian strategies I examined above (Europe) or, alternatively, stress the importance of changing cultural values, which they consider as being amenable to change even within the existing institutional framework and outside an antisystemic movement (USA). Therefore, the Green movement has abdicated any antisystemic or liberatory role and today is, directly or indirectly, reformist. Directly, in the case of parliamentary Green parties and red-Green organisations, and indirectly in the case of movements like deep ecology which emphasise 'spiritual change over political and social change, and the cultivation of a reverential consciousness or sensibility about the natural world rather than organization and movement building'. ${ }^{13}$

Also, in the same way that the victory of 'realos' over the 'fundis' led to the end of the Green movement as a potentially antisystemic movement, the victory of 'insiders' (i.e. the liberal feminist groups oriented toward gaining position and power within the system) over the 'outsiders' (i.e. the autonomous women's' movement oriented to revolutionary change) led to the end of the feminist movement as a potentially antisystemic movement. Furthermore, in exactly the same way as the decline of the Left in general, which began in the early 1970s, has induced many anarchists to substitute lifestyle for politics and 'spirituality' for rational analysis, the decline of the feminist movement has induced many feminists to substitute 'cultural feminism' for radical feminism and spiritualism for rationalism. At the same time, as I stressed elsewhere, ${ }^{14}$ ecofeminism, which is particularly influential among radical feminists, not only adopts an anti-industrial rather than an anti-capitalist analysis but also supports a kind of utopian reformism aiming to reform the present system through a series of subsistence activities, which in the North involve life-style activities and easily marginalized communes whereas in the South 
involve activities that are mainly the remnants of the premodern society -- gradually being phased out under the pressure of the internationalised market economy.

The identity politics movement is, today, the form of postmodern politics par excellence, as its politics of promoting the special interests of specific groups (feminist, gay, ethnic minorities and so on) fits well to the anti-universalist character of postmodern theory. Thus, today's 'identity' movements, despite the radical critique they raise against specific hierarchical structures, (like those based on gender, race, sexual repression and repression of minorities), never advanced any comprehensive political project for systemic change --their fragmented nature does not allow such a program anyway-- but instead promoted cultural and personal identity issues.

Coming now to the postmodern strategies, the postmodern strategy of alliances is the main form of Left politics today. The rationale behind this strategy is based on the belief that the participants in universalist movements, like the Marxist movement, have no validity as a separate category of social existence, whereas the participants of 'localised' struggles can safeguard the sense that individuals really are constituted as a sum total of 'subject positions' and, at the same time, preserve the sense that they are part of a broader struggle for self-determination and equality. However, it is obvious that, the lack of any common anti-systemic aim, in combination with the composition of such alliances, which would unavoidably consist of heterogeneous movements with sometimes conflicting aims, is bound to lead them across the well-trodden path of reformist politics that are hopelessly inadequate to deal with the multidimensional crisis we face in today's' internationalised market economy. This is the case of the alliances within the anti-globalisation 'movement" or the movements against neoliberalism. It is clear that the strategy of alliances and coalitions between and amongst heterogeneous groups adopted by supporters of this strategy unavoidably leads to a fundamental lack of unity, even on short-term goals, as it becomes obvious by the fact that the only common objective of those supporting such alliances is a negative one ('anti'-globalisation or 'anti'-neoliberalism) with no vision of a future society and a long-term strategy. No wonder that as the issue of a universal social change is not even raised by supporters of this strategy, its potential is limited to the possibility of effecting some social reforms within the existing system of market economy and representative 'democracy'.

Similarly, the 'radical democracy' politics aims at embracing the 'new social movements'/identity movements as multiple sources of 'radical' change that can bring about 'radical democracy' and at the same time integrate the 'politics of difference'. However, as I attempted to show elsewhere, ${ }^{15}$ the conception of radical democracy involves in effect a process of "extending and deepening" the present political and economic 'democracy', which is based on the separation of society from polity and Nature, within a system founded on the market economy and representative 'democracy'.

As I will try to show in the second part of this paper, the truly radical objective today is to fight for the creation of a new anti-systemic movement aiming at the equal 
distribution of political and economic power. This implies the need for a new liberatory politics, like that proposed by the Inclusive Democracy (ID) project, that would be a synthesis of the 'universalist' politics that characterised the radical movements of modernity with the 'politics of difference' that came into the forefront in the last quarter of a century with the emergence of the 'new social movements'. The inclusive democracy paradigm, while recognising the different identities of the social groups that constitute various sub-totalities, at the same time locates these differences into an overall socioeconomic system which institutionalises the concentration of power between and within various social groups. Thus, whereas in the postmodernist paradigm it is the identity-based hierarchical structures which define the 'particularistic' character of the localised struggles around identities, in the inclusive democracy paradigm it is the concentration of power in all its forms, as a result of the prevailing power relations and structures, that defines the 'universalist' character of the social struggle today.

Instead, therefore, of "alliances and coalitions between and amongst groups otherwise engaged in 'single issue' politics," ${ }^{16}$ the ID project proposes the building of a mass programmatic political movement which would unite all the members of social groups, who potentially form the basis of a new emancipatory subject, on the basis of a common paradigm. The ID strategy is based on the explicit recognition of the multiple 'subject positions' of individuals participating in various social groups ${ }^{17}$ and consequently supports localised struggles-provided, however, that they are an integral part of a political movement for anti-systemic change on the basis of a comprehensive programme for systemic change that reintegrates society with economy, polity and Nature, through the institutionalisation of the necessary (but not sufficient) conditions for the equal distribution of power at all levels.

\section{2. 'Antisystemic' strategies}

The common characteristic of antisystemic strategies is that they all aim, through a revolutionary change (violent or peaceful) to a 'systemic' transformation of society that involves the replacement of the present political, economic and social institutions with new forms of social organisation. The main antisystemic strategie s are the statist socialist strategy, the guerrilla strategy, the libertarian socialist strategy and the Libertarian Municipalism strategy, which we shall consider in this part of the paper, as well as the inclusive democracy strategy that we shall consider later.

The statist socialist strategy: 'revolution from above'

This strategy is very much a product of modernity and of the growing realisation among activists in the middle of the 19th century, who absorbed the lessons that 
oppressed groups earned from the suppression of the 1848 uprisings, that 'spontaneous' uprisings cannot lead to a systemic transformation. It was this realisation that led to the creation of the first organised antisystemic movements. ${ }^{18}$ The Marxist- Leninist tradition of statist socialism is a classical example of a strategy aiming at a 'revolution from above' and despite attempts by today's Marxists to differentiate between Marx and Lenin on the issue of strategy, in fact, the sperms of Leninist totalitarianism, which culminated in Stalinism, can be found in Marx's thought itself. This becomes obvious if one takes into account two crucial characteristics of Marx's theoretical system which were first criticised (though not in a systematic and coherent way) by Bakunin.

The first was the 'communism-through-statist socialism' characteristic of Marxist strategy which involved the conquest of state power by a victorious proletariat and the establishment of a proletarian state which would eventually lead to a communist society. However, this would not happen before the rapid development of productive forces (which the socialisation of production relations will bring about) has already led to the abolition of scarcity and division of labour and the withering away of the state. But, as I attempted to show elsewhere ${ }^{19}$, the Marxist abolition of scarcity is in fact a myth depending on an objective definition of 'needs', which is neither feasible nor desirable and can be used by those controlling the state machine in a socialist society for the indefinite maintenance of state power and power relations and structures in general. Furthermore, it is inconceivable that a state, which represents the epitome of the separation of polity from society, even if it is a proletarian one, will preside over its own abolition!

The second was the equally untenable ${ }^{20}$ Marxist attempt to convert the socialist project into an 'objective' science of social change. This could easily lead, as it did in Lenin, to the need for socialist consciousness to come 'from without'. This is because scientific consciousness arises independently of the social movement that leads to socialism and must therefore be intro-duced into that movement from without. Still, for Marx, the problem (supposedly) does not arise, since sc ience is seen as the unity of theory and practice that not only interprets reality but also becomes part of the force changing it, a part of praxis, that is, the conscious determinate shaping of history. In this sense, science is identified with the movement itself which makes that doctrine its own. However, as several Marxist writers have shown, ${ }^{21}$ Marxism is then transformed into a theology. In other words, for Marxism to keep its 'scientific' character it would have to see practice not as creating truth but as merely ascertaining its occurrence in which, case however, scientific consciousness has to be assumed as arising independently of the social movement that leads to socialism and must be intro-duced into that movement from without. But, then, as Kolakowski ${ }^{22}$ points out, 'there is no reason not to draw the same conclusion from this state of affairs as Lenin did'.

The Leninist strategy was based on the implicit assumption (Gramsci's ${ }^{23}$ not always clear requirement that the proletarian culture should ha ve become 'hegemonic' before its actual attaining political power notwithstanding) that the change in the social paradigm --even among a minority of the population, that is, the vanguard of the 
proletariat (organised in the communist party and equipped with the 'science' of socialism, i.e. Marxism) -- could function as a catalyst to bring about a socialist revolution. Thus, for Lenin $^{24}$, workers are not able, on their own, to develop a scientific theory of socialism, a task which historically has been left to the intellectuals. However,, as Marcuse pointed out, this problematique easily ends up with the custodians of the scientific orthodoxy, the party, or rather the party leadership, to appear 'as the historical repository of the 'true' interests of the proletariat and above the proletariat'. ${ }^{25}$ No wonder that, as the same author aptly stresses, 'a straight road seems to lead from Lenin's 'consciousness from without', and his notion of the centralised authoritarian party, to Stalinism' ${ }^{26}$

History has confirmed that this strategy could only lead to new hierarchical structures, as the vanguard of the working class becomes at the end the new ruling elite ${ }^{27}$. This was the main lesson of the collapse of 'actually existing socialism' which has clearly shown that if the revolution is organised, and then its program carried out, through a minority, it is bound to end up with new hierarchical structures rather than with a society where concentration of power has been abolished. In fact, the combination of the Marxist conversion of the socialist project into an 'objective' science with the Leninist strategy of organising the vanguard on the basis of 'democratic centralism' (a principle ensuring the power of a small party elite over the entire movement) proved lethal, as it decisively contributed to the establishment of new hierarchical structures, initially, in the socialist movement and, later in society at large. It is of course a well-known historical fact that in both the pre-revolutionary Marxist movements, as well as in the post-revolutionary governments, the justification of the concentration of power in the hands of the party elite was based on the 'fact' that they alone 'knew' how to interpret history and take appropriate action in order to accelerate the historical process towards socialism. Not surprisingly, the basis of the new hierarchical structures was the social division created between the avantgarde, which alone was in an objective position to lead the movement (because of its knowledge of the 'scientific' truth that Marxism embodied) and the 'masses'.

\section{The guerrilla strategy}

The only successful case of conquest of power through a guerrilla strategy which is still alive today is the Cuban case which, according to one of its protagonists, Che Guevara, "showed plainly the capacity of the people to free themselves by means of guerrilla warfare from a government that oppresses them ${ }^{28}$. For Che, the Cuban guerrilla strategy was important in demonstrating that :

1) Popular forces can win a waragainst the army.

2) It is not necessary to wait until all conditions for making revolution exist; the insurrection can create them 
3) In underdeveloped America the countryside is the basic area for armed fighting.

In an explicit rejection of the traditional Marxist strategy followed by many Latin American 'pseudo-revolutionaries', as Che called them, this new strategy was not dependent on waiting until in some mechanical way all necessary objective and subjective conditions are given, without working to accelerate them. However Che was realistic enough to recognise that one should not jump to the conclusion that all conditions for revolution are going to be created through the impulse given to them by guerrilla activity: ${ }^{29}$

it must always be ke pt in mind that there is a necessary minimum without which the establishment and consolidation of the first centre is not practic-able. People must see clearly the futility of maintaining the fight for social goals within the framework of civil debate. When the forces of oppression come to maintain themselves in power against established law, peace is considered already broken. In these conditions popular discontent expresses itself in more active forms. An attitude of resistance finally crystallises in an outbreak of fighting, provoked initially by the conduct of the authorities. Where a government has come into power through some form of popular vote, fraudulent or not, and maintains at least an appearance of constitutional legality, the guerrilla outbreak cannot be promoted, since the possibilities of peaceful struggle have not yet been exhausted.

It is therefore obvious that, for Che, the guerrilla strategy should not be used in cases where some sort of representative 'democracy' is in existence. This is an important qualification because it rules out the use of this strategy almost everywhere today given that, after the collapse of 'actually existing socialism', the transnational elite ${ }^{30}$ does not resort anymore to the use of open dictatorial regimes for the reproduction of the market economy system but relies instead on its traditional political complement in the North: representative 'democracy'. The combination of this political system with the all-powerful mass media (particularly TV which has spread to every corner of the earth today), is the most effective method of population control that ruling elites have ever created. The goal of representative 'democracy' is to create a false impression of popular control, whereas in fact it secures the concentration of political power at the hands of local elites loyal to the transnational elite. On the other hand, the goal of mass media is to propagate on a massive scale the values of the dominant social paradigm which legitimise the market economy and representative 'democracy'.

This change in tactics on behalf of the transnational elite is the obvious explanation for the present decline of guerrilla movements today, even in the birthplace itself of the guerrilla strategy, i.e. Latin America. Furthermore, as the Nicaraguan case (and Afghanistan's case today) has shown, the transnational elite is able, through the use of some sort of contras' army financed and armed by it (in combination with its lethal air power -if needed) to bring about the downfall of any regime which is not of its liking. Particularly so, if it does not enjoy the active support of the majority of the population-an 
unavoidable result of the fact that the guerrilla strategy itself is incompatible with a process that will create a new democratic consciousness, given the necessarily hierarchical structure of the military organisation needed to carry on the guerrilla warfare. The inevitable outcome is an organisational structure which is bound to lead to new power structures and relations of inequality once it takes power. This applies for instance to the few remaining antisystemic guerrilla movements today like Colombia's FARC.

Still, there is the case of the Zapatistas which, as Iain Watson ${ }^{31}$ argues, is basically 'representing a politics of resistance to globalisation that cultivates a project of radical democracy'. However, as I stressed above, the radical democracy conception is both ahistorical and utopian in the negative sense of the word because, far from aiming at creating new institutions to replace the present bankrupt institutional framework, simply proposes 'deepening' representative 'democracy' --or, as Marcos put it in suggesting a similar conception, creating a 'more balanced' representative democracy which would 'enrich' itself with direct democracy, ${ }^{32}$ and a 'different' globalisation, through the introduction of social controls on the market economy. However, the very fact that the antiglobalisation movement, (as far as it is dominated by the reformist currents within it -ATTAC etc), as well as the Zapatista movement itself, presently show clear signs of being marginalized, or worse, being integrated within the existing institutional framework, provides a clear illustration of how effective a politics of resistance to globalisation based on radical democracy conceptions is in drastically altering the course of neoliberal globalisation, let alone in functioning as a transitional strategy to an alternative society. No wonder that Alexandros Gezerlis, ${ }^{33}$ far from characterising the Zapatistas as an antisystemic movement, aptly called it 'the first ever postmodern guerrilla army', given that their politics fits in perfectly, on the one hand, with the anti-universal character of postmodern politics, as the politics of promoting the special interests of specific groups (ethnic minorities in this case) and, on the other, with a general opposition to neoliberalism, as a kind of 'bad policy' rather than as the inevitable outcome of the dynamics of market economy.

\section{The libertarian socialist strategy: 'revolution from below'}

The 19th century socialist split, which reached its climax in the dispute between Marx and Bakunin within the First International, led to the emergence of the statist socialist strategy that we discussed above and the libertarian socialist strategy. Today, almost a century and a half since this debate, the socialist project is in ruins after the collapse of both versions of statist socialism i.e. the reformist socialdemocracy in the West and the revolutionary statist socialism in the East. Furthermore, despite the fact that libertarian socialism still remains untried, (after the most serious attempt to implement its principles during the Spanish civil war was stifled by the fascist hordes, which were acting under the tolerant eye of Western 'democracies'), the collapse of the statist version of socialism has not led to a revival of its libertarian version. Instead, the institutional 
framework defined by modernity (i.e. the market economy and liberal 'democracy') has become universal and, consequently, the chronic multidimensional crisis (political, economic, ecological, social and cultural) which arose with the emergence of this institutional framework has also been universalised and exacerbated.

The libertarian socialist strategy is one involving a 'revolution from below'. As such, it aims at systemic change through the abolition of state power and the creation of federations of communes, or of workers' associations. The various trends within the anarchist movement (community-oriented versus worker-oriented) aim at revolution in order to abolish state power and transform society 'from below', rather than in order to conquest state power and transform society 'from above', as the statist socialist strategy does. An obvious example of a community-oriented strategy is the one suggested by the libertarian municipalist trend to be discussed below whereas the anarcho-syndicalist movement is a clear case of a worker-oriented strate gy.

The latter advocated direct action by the working class to abolish the capitalist order, including the state, and to establish in its place a social order based on workers organized in production units. The reliance upon direct industrial action stemmed from a rejection of reforms achieved through the state that was considered an appendage of the capitalist system, as well as from the practical considerations that, outside the factory, political differences among workers would come into play, possibly hindering mass action whereas inside it, their similar employment status gave workers a sense of solidarity. The Anarcho-Syndicalists argued in favour of a militant form of trade unions dedicated to the destruction of capitalism and the state that would aim to take over factories and utilities, which would then be operated by the workers. To sustain militancy, an atmosphere of incessant conflict should be induced, and the culmination of this strategy should be the general strike.

However, although several general strikes, with limited objectives, were undertaken in France and elsewhere with varying success at the beginning of last century, the decisive general strike aimed at overthrowing the social order in a single blow was never attempted. So, the anarcho-syndicalist movement, after flourishing in France, chiefly between 1900 and 1914, and to a significant extent in Spain, Italy, England, the Latin-American countries, and elsewhere, by the beginning of the second World War had withered away. The major attempt for a revolution from below in Spain led to a civil war, where the superior means, organisation and efficiency of the fascist enemy (as well as of statist socialists who undermined in every way possible the libertarian socialists) led to the suppression of libertarian socialists. Similarly, the only major attempt for a revolution from below in the post war period, in May 1968, ended up as an unsuccessful attempt for a systemic change with statist socialists (revolutionaries or reformists) eventually prevailing over the libertarians. In the same way, one could easily foresee that the insurrectionary situation that has recently developed in Argentine cannot lead to a systemic change towards a comprehensive political and economic democracy. In the absence of a mass democratic antisystemic movement, the present situation could easily lead to a new 
bloodbath engineered by a temporary military regime, or simply to a continuation of the same 'democratic' regime with a change in the personnel of the political elite and the implementation of milder versions of the present policies aiming at a further integration of Argentina into neoliberal globalisation.

\section{The Libertarian Municipalism strategy}

The strategy of Libertarian Municipalism (LM) expresses the politics of social ecology which has been theorised by Murray Bookchin ${ }^{34}$ and recently codified by Janet Biehl. $^{35}$ I will not examine here in detail the philosophical and conceptual differences between the social ecology/LM and the ID projects, something that I have already done elsewhere ${ }^{36}$ but I think that a brief description of these differences is necessary given their significance as regards the goals and the strategies of the two projects.

As I attempted to show in Towards An Inclusive Democracy (TID), the project for a democratic society cannot be grounded on an evolutionary process of social change, either a teleological one (such as Marx's dialectical materialism) or a non-teleological one (such as Bookchin's dialectical naturalism). Therefore, whereas in the ID problematique there is no dialectical process leading to an inclusive democracy, which therefore can only be the outcome of praxis based on a political project, in the LM problematique a democratic ecological society is the outcome of human activity, which takes place within a process of Progress, defined as 'the self-directive activity of History and Civilisation towards increasing rationality, freedom, ${ }^{37}$. However, this is an assumption which, as I attempted to show elsewhere ${ }^{38}$, is both untenable and undesirable. Still, it is within this process of Progress that the development of productive forces, according to Bookchin, leads to a 'post-scarcity' societyalthough the huge inequality between classes, regions and countries that the capitalist organisation of society imposes does not allow, at present, the potentiality of post scarcity society to be realised in its full actuality.

?f one adopts, as social ecology does, this communistic fiction of a post-scarcity society there is no need for a democratic mechanism to allocate scarce economic resources, i.e. there is no need for an economic democracy. All that is required is a set of moral principles to guide sharing, a moral economy. ${ }^{39}$ This is why Bookchin never bothered to propose a mechanism for the allocation of resources, ${ }^{40}$ alternative to the market and planning mechanisms, and insists instead that in a communistic post-scarcity society 'the very idea of an economy has been replaced by ethical (instead of productive) relationships; labour units, Proudhonian contracts, Rawlsian justice, and the like would not even be relevant'. Therefore, social ecology's conception of a democratic society presupposes the existence of some material preconditions for freedom, as the entrance to the realm of freedom depends on 'objective' factors, like the arrival of the mythical state of affairs of material abundance. 
On the other hand, in the ID problematique, the link between post-scarcity and freedom is broken. The abolition of scarcity and, consequently, of the division of labour is neither a necessary nor a sufficient condition for democracy and the ascent of man from the kingdom of necessity to the kingdom of freedom (hypothesised from Aristotle, through Locke and Marx, to Arendt and Bookchin), is de-linked from the economic process. Historically, anyway, there have been several occasions when various degrees of freedom survived under conditions that could be characterised as belonging to the 'realm of necessity'. Furthermore, once we cease treating the two realms as mutually exclusive, there is no justification for any attempt to dominate Nature-an important element of Marxist growth ideology_-in order to enter the realm of freedom.

As a result of these fundamental philosophical differences between social ecology and the ID problematique, some crucial differences emerge as regards the conceptions of democracy used by the two projects and, consequently, the strategies proposed. Thus, social ecology/LM centres its conception of democracy on the political realm, at the exclusion of the other realms. This is the inevitable outcome of the fact that Bookchin uses a narrow conception of the public realm (in contrast to the private or social realm which encompasses production and economic life) that includes only the political realm (the realm of real politics) and the State (the realm of statecraft). As a result, first, there is no conception of economic democracy in the LM scheme --something that led to insinuations by statist socialists that libertarian municipalism may implicitly rely on a market allocation of resources ${ }^{42}$. Furthermore, in the LM scheme there is no conception of 'democracy in the social realm' (the workplace, education institutions, the household etc)-something that rendered it vulnerable to accusations by feminists, social statists and others that it effectively ignores the issues of 'identity differences', and the differences between citizens as workers and citizens as citizens.

Michael Albert, for instance, pursues aggressively the latter criticism and accuses libertarian municipalism for putting politics in charge of economics. However, although there is some basis in this criticism, given the narrow conceptions of the public realm and democracy adopted by social ecology, still, statist socialists like Albert hardly qualify to raise such criticisms. This is because his own project of participatory economics is characterised, first, by an obvious lack of understanding of the meaning of individual and social autonomy and therefore of the incompatibility of representation (which he adopts) with democracy. ${ }^{43}$ Second, as I stressed in TID, not only does Albert \& Hahnel's Parecon model $^{44}$ involve a highly bureaucratic structure that was aptly characterised as "participatory bureaucracy" and which, together with the multiplicity of proposed controls to limit people's entitlement to consume, "would lay the ground for the perpetuation or reappearance of the state" 45 , but it also involves a serious restriction of individual autonomy in general and freedom of choice in particular, as a result of its exclusive reliance on planning for the allocation of resources, which could easily end up with a new type of authoritarianism ${ }^{46}$. 
On the other hand, the ID project expands the traditional public realm to include any area of human activity where a democratic decision-taking process is possible, i.e. the political, economic, ecological and 'social'(not in the sense of the private) realms. Thus, the political realm is defined as the sphere of political decision-taking, the area where political power is exercised, which can take the form either of political (direct) democracy, as defined by the ID project, or of representative (liberal/parliamentary) 'democracy', as at present. Similarly, the economic realm is defined as the sphere of economic decisiontaking, the area where economic power is exercised with respect to the broad economic choices that any scarcity society has to make, which can take the form either of economic democracy, as defined by the ID project, or of a market economy (as at present), or a planned economy (as in the case of 'actually existing socialism'). Finally, the social realm is defined as the sphere of 'social' (in the broad sense) decision-taking, the area where 'social' power is exercised (workplace, education place, mass media, cultural institutions etc), which can take the form either of a democratic process, as defined by the ID project, or of hierarchical structures, as at present. To these we have to add an "ecological realm", defined as the sphere of the relations between the natural and the social worlds, which can take the form either of reintegrating society with nature, as proposed by the ID project, or of attempting to dominate nature, as at present. The remaining areas of activity and individual decision-taking belong to the private realm.

The implication of the above expansion of the public realm is that the ID problematique uses a multidimensional conception of democracy which expresses a synthesis of the democratic and socialist traditions with the demands of the radical new social movements. Thus, political democracy, economic democracy and democracy in the social realm aim at the equal distribution of political, economic and social power respectively whereas ecological democracy aims to reintegrate society and nature. ${ }^{47}$

Therefore, despite some common elements between the ID and LM projects, the crucial philosophical and conceptual differences that I mentioned at the beginning imply different strategies for the transition to an alternative society. Thus, the LM strategy, as described by Bookchin, aims "to transform and democratise city governments, to root them in popular assemblies, to knit them along confederal lines, to appropriate a regional economy along confederal and municipal lines." 48 In other words, the goal is to develop "a public sphere--and in the Athenian meaning of the term, a politics--that grows in tension and ultimately in a decisive conflict with the state." 49 So, in the LM transitional strategy there is no scope for the building of institutions of economic democracy and of democracy in the social realm, as a means of creating a rupture with the dominant social paradigm and generating the 'majority' democratic consciousness that will lead to a confederal inclusive democracy. Instead, the entire LM strategy is based on the exclusive goal of 'reclaiming the political realm'. ${ }^{50}$ This is the inevitable consequence of the fact that the LM project's aim is to build a political democracy rather than an inclusive democracy, as in the ID project in which political democracy is only one component of inclusive democracy. Bookchin and Biehl are explicit on this when they state ${ }^{51}$ : 
Community--cooperative food shops and cafes, communes, production collectives, and the like....are not in themselves libertarian municipalist institutions, since they are part of the social realm rather than the political realm. Nor, given the capitalist system in which they are embedded, can the persistence of their cooperative nature be relied upon.

However, although it is true that such alternative economic institutions may easily be marginalized or integrated into the market economy, this would not necessarily happen unless the activities of those involved in establishing and running such institutions do not constitute part of a systemic transitional strategy with its own goals and means but simply represent some kind of 'lifestyle anarchism'.

Finally, the LM strategy does not involve the creation of an alternative political organisation, like the one described here, and relies instead on the creation of groups with the sole aim to 'reclaim the political realm' by functioning as catalysts for the creation of citizens' assemblies $^{52}$--a totally inadequate aim not only for the creation of an inclusive democracy but even for the creation of an 'inclusive' democratic consciousness.

In conclusion, the LM strategy could, at best, create a consciousness for political democracy and not for economic and ecological democracy, as well as a democracy in the social realm. The creation of such an 'inclusive' consciousness requires citizens to experience for themselves an inclusive democracy in practice and this can only be achieved if they take active part in the establishment and in the running of alternative political, economic and social institutions, rather than simply political institutions, as LM suggests.

\section{3.'Intermediate' strategies}

\section{'Lifestyle anarchism' strategies}

As I mentioned above, we may characterise as 'Lifestyle anarchism' strategies all those, spontaneous or not, activities in the economic or broader social realm, which are not an integral part of a political project for systemic change. Such activities may involve the building of communes or ecovillages as well as Community Supported Agriculture, farmers markets, land trusts, LETS, local economic development and alternative 
technologies. I will therefore classify as 'lifestyle' activists all those who are involved in such activities for their own sake, (even if they use antisystemic slogans to justify them), rather than with the explicit aim to build a new political antisystemic movement with a clear vision about a future society and a strategy to reach it. Although Bookchin, who coined the term 'lifestyle anarchism', did not specifically describe which activities may be included here I think that the above activities often present many of the characteristics attributed by Bookchin to it: assailing organization, programmatic commitment and se-rious social analysis, as well as rejecting the need for building a political movement (unlike the anarcho-syndicalist movement which in its heyday tried to en-gage in creating an organized movement as we have seen above) and relying instead on bringing social change 'by example' and the corresponding change in values. The motive behind such activities, as Bookchin described it, in fact 'articulates Foucault's approach of 'personal insurrection' rather than social revolution'. 53

Such activities are rampant in countries like Britain since the 1970s, when the ideas of Colin Ward (and others around him) concerning what they called 'Anarchy in Action' --in fields as diverse as town planning, housing, education and allotments-became influential. Similar trends are expressed today by various anarchist currents that extol the virtues of co-ops, which they consider as 'anarchism in its latest practical manifestation', since 'they allow the practice of anarchism to be conducted within the larger capitalist economy', 54 or adopt a 'pragmatic' anarchism, which rejects the traditional antisystemic demands of anarchists to abolish the market economy and money! ${ }^{55}$ However, it is utterly a-historical to suggest, as some 'pragmatic' (lifestyle) anarchists $^{56} \mathrm{do}$, that in the same way as capitalism evolved out of feudalism, a new liberatory society could emerge in the future out of the alternative institutions being established today by activities involved in 'anarchy in action'. The fundamental flaw in such analysis is that the capitalist society was indeed an evolutionary development, but not so much as regards its economic and political institutions, in the establishment of which (as I attempted to show elsewhere ${ }^{57}$ ) the state played a crucial role. In fact, the capitalist society was an evolutionary development mainly as regards its heteronomous character, i.e. the fact that a new capitalist elite had simply replaced the old feudal one. However, a liberatory society is an autonomous society, a completely different 'species' of society, that involves the abolition of the institutional concentration of power at the hands of various elites. This is a revolutionary change which can never be achieved through some kind of evolution, even if such evolution could be speeded up by the activities of 'anarchists in action', lifestyle anarchists etc, who are involved in establishing alternative institutions here and there, outside of a political programmatic movement, with its own goals, means and strategy.

As Bookchin stressed, the important differences between life-style and LM strategies center around the role of the individual with respect to social change. In lifestyle strategies, social change is seen to start from the lifestyle of the individual, and to proceed through bypassing the state and the market economy, rather than through contesting and attempting to replace them with new social institutions. On the other hand, 
the LM strategy emphasises the role of the social individual, that is, of the individual who takes part in political struggles at the local level and social struggles in general, with the aim to effect social change, not 'through setting an example', but through creating a confederation of municipalities which will be in tension with the nation-state, until the former replaces the latter. ${ }^{58}$ The ID project, although of course also stresses the role of social individual in social change, still, it uses a concept of freedom in terms of individual and social autonomy which aims to transcend the duality of individualism versus collectivism $^{59}$ and, in this sense, is differentiated from the LM project which adopts collectivism.

The emphasis assigned to the individual (rather than to the social individual) by lifestyle strategies and the similar 'anarchy in action' strategies has inevitably led to social marginalization, as the almost insignificant social impact of movements inspired by such strategies has shown in the last 25 years. Furthermore, this trend, inevitably, has not escaped the trap of being "so skewed towards the idea of the reforms of the individual's values and lifestyle, as the primary political route to radical social change, that it ends up seeming positively antipathetic to the notion of the collective"60--the New Age movement being a clear indication of this trap.

Furthermore, the activities of the people involved in this sort of 'anarchy in action'/lifestyle anarchism in no way constitute a movement, let alone a political movement. First, there is no common organisation, something that implies that we should more accurately call the groups involved in such activities as spontaneous gatherings of people with similar ideas and values rather than 'organised movements' worthy of this name. Second, the activists involved do not share a common worldview. Furthermore, as the activists involved in such diverse activities have never put forward any kind of common program with shared goals, ideology and strategy we cannot talk about a common set of values characterising the participants in these 'movements'. Finally, the activities of many of the participants involved are in no way related to antisystemic politics (in the sense of promoting an alternative society), if indeed they are related to politics at all! In fact, all too often some of the activities involved are so politically harmless that the political elites frequently use them for their own ends.

As I pointed out elsewhere, ${ }^{61}$ this sort of activity is utterly ineffective in bringing about a systemic change. Although helpful in creating an alternative culture among small sections of the population and, at the same time, morale boosting for activists who wish to see an immediate change in their lives, this strategy does not have any chance of success-in the context of today's huge concentration of power-to create the democratic majority needed for systemic social change. This is because the projects suggested by this strategy may be too easily marginalized, $\alpha$ absorbed into the existing power structure (as has happened many times in the past) while their effect on the socialisation process is minimal--if not nil. Particularly so, when such strategies usually concentrate on single issues, which are not part of a comprehensive political program for social transformation and, therefore,, do not help in creating the 'anti-systemic' consciousness required for 
systemic change. Finally, systemic social change can never be achieved outside the main political and social arena. The elimination of the present power structures and relations can neither be achieved "by setting an example", nor through education and persuasion. A power base is needed to destroy power and the only way in which this goal could be consistent with the aims of the democratic project would be, to my mind, through the development of a comprehensive program for the radical transformation of society that will start with the transformation of local political and economic structures.

The last point becomes particularly important if we take into account that values, which are crucially influenced by the dominant social paradigm, cannot change independently of a change in structures at a significant social scale. It is therefore not surprising that the implicit, or sometimes explicit, assumption made by many activists involved in such activities ${ }^{62}$ is that values have to change first and an eventual 'structural change' will follow. This is in contrast to the Marxist approach in which structures have to change first through the building of an antisystemic movement. On the other hand, the ID approach involves a synthesis of these two approaches as well as of the direct action approach (to be considered below). Thus, according to the ID strategy, the change in values is interlinked with and dependent on the change in structures at a significant social scale. It is within the struggle against the present institutions and the parallel process of creating alternative ones that a mass antisystemic movement can be created, a movement which will be based on a new revolutionary consciousness and system of values. This is because the aim of the creation of a genuine democratic consciousness among citizens presupposes a 'living experience' of democracy -something that can only be realised through the parallel introduction of new institutions of political and economic democracy. This can only be done within the context of an antisystemic movement meeting the conditions described above -a movement which is engaged both in a struggle to fight the existing system and to build in parallel the new institutions, through the creation of what I call local inclusive democracies that involve the introduction of new political, social and economic institutions at a significant social scale. Such a new movement could play the role of the catalyst for the transition (which does not necessarily have to be a violent one) to a confederal inclusive democracy..

So, the issue that arises here is: shall we dismiss such lifestyle activities, as Libertarian Municipalism does, just because they belong to the social or economic realm? Or, alternatively shall we see them, as Ted Trainer ${ }^{63}$ does, as 'the best way available to us now to begin to build the mass movement'? The ID project's answer to both these questions is negative. Building alternative economic and social institutions within the present system is as necessary as the building of alternative political institutions in the form of citizens' assemblies. However, unless such activities take place as an integral part of a political project with clear antisystemic goals, means and strategies, they do not have any potential of developing into a mass movement and will never lose their lifestyle character, being in the process easily marginalized or integrated within the system --as happens at present. 
It is therefore clear that we need a new strategy that constitutes a synthesis of the old Marxist approach, which is based on the creation of an antisystemic movement to fight against the present system, the anarchist approach, which is based on 'prefiguring' i.e. building the new within the old, and finally the approach proposed by the 'new' social movements (feminist, Green etc), which proposes democratic forms of organisation and direct action activities This implies creating a democratic political organisation with clear antisystemic goals and means which will fight for the creation of a new mass antisystemic movement aiming at an inclusive democracy, in other words, a movement that will combine the fight against the present system with the parallel struggle to create a new system within the old.

\section{The direct action strategy}

Supporters of direct action activities, which range from disruptive protests (occupations, blocking of roads etc) and mass demonstrations (violent or not) up to a general strike, may have reformist or antisystemic aims. Thus, for reformist supporters of direct action like Peter Hain (who in his youth was a fervent supporter of direct action but presently, as a member of Tony Blair's government, is an enthusiastic supporter of the bombing of Yugoslavia and Afghanistan!) direct action is 'a legitimate and vital means of pushing forward the frontiers of democracy, ${ }^{64}$ 'of freedom and social justice'. ${ }^{65}$ For reformists like him, 'direct action is essentially a personal form of action springing from the individual's conscience...(to achieve) change through confrontation rather than through negotiation' -although, in his view, confrontation should be strictly restricted to violence against corporate property and should never take the form of urban guerrilla warfare with bomb attacks against property. ${ }^{66}$

On the other hand, for antisystemic supporters of direct action, it has always been an important weapon for social change, particularly in the form of a general strike. However, whereas for anarchosyndicalists the general strike was seen as a means of inaugurating the social revolution, for Marxists like Rosa Luxemburg, the 'mass strike' was adopted for different reasons. Thus, Luxemburg was very critical of the anarchist position on the matter and saw the mass strike "not as a means of jumping suddenly into the social revolution by means of a theatrical coup, but as a means, principally, of creating for the proletariat the conditions of the daily political struggle and especially of parliamentarianism' ${ }^{67}$

Today, direct action is used by both anarchists and Marxists, but also by reformists.The anti-globalisation 'movement', in which all these trends mix together, is a clear illustration of this. In fact, as I stressed elsewhere, ${ }^{68}$ it is the very heterogeneous nature of the various groups participating in the antiglobalisation actitivities, which could hardly characterise its participants as a 'movement'. Thus, reformist currents within this movement (NGOs, trade unionists, mainstream Greens and others) mainly see the anti- 
globalisation activities as a form of civil disobedience with the aim to 'resist' globalisation, whereas radical currents see it as a means of 'educating' people on the need for systemic change, which eventually might actually lead to it.

However, the grave error made by the reformist Left that adopts a 'non-systemic' approach to globalisation--an approach adopted by Marxists like Amin, Wallerstein, Panitch et al and libertarians like Noam Chomsky-- is that they assume that neoliberal globalisation is reversible, even within the system of the market economy and representative 'democracy'. The logical consequence of such a stand is the adoption of direct action strategies to 'resist' neoliberal globalisation, as if the latter is reversible through the tactics of civil disobedience, similar to the ones used in opposition to the Vietnam War! But, as I attempted to show elsewhere, ${ }^{69}$ neoliberal globalisation is not a matter of policy (as the Vietnam war was), or even a matter of choice for the elites, and therefore is not reversible within the existing institutional framework. As we have seen above, a market economy today can only be an internationalised one, given that he growth (and therefore profitability) of the TNCs, which control the world market economy, depends on open and 'liberated' markets worldwide. This means that even the introduction of effective social controls over the internationalised market economy for the protection of the environment and labour is impossible today. This implies that, at most, all that the anti-globalisers could hope to achieve with their action is some sort of reforms (painless for the elite) like the Tobin tax, or similar measures pursued by ATTAC, the Porto Allegre World Social Forum etc), i.e. a 'globalisation with a human facade'.

It is therefore clear that the antiglobalisation 'movement', in its present form, will not be able to transcend its current character as an organised 'resistance movement' of the 'multitude' against the 'empire' --as Hardt \& Negri ${ }^{70}$ describe the reformist resistance against globalisation. It is not therefore difficult to predict that if the radical currents within this 'movement' do not prevail, it will either be phased out in the future, or simply be transformed into another kind of 'new' social movement (like, for instance, the green movement) and integrated within the 'system' soon afterwards.

But, what about the potential of the antiglobalisation movement, or generally any direct action movement, as an educational means towards systemic change? The answer here crucially depends on the 'context' of such direct action. If this context is, as in the case of the antiglobalisation movement, one of a consensus platform, which would necessarily express the lowest common denominator of the demands of the various activists taking part in it, such a potential is nil. This is because such a platform will inevitably be a reformist one and the 'reformism-as-strategy' approach has blatantly failed in the past to create an antisystemic consciousness at any significant social scale. ${ }^{71}$ On the other hand, if the 'context' of direct action is a movement with clear antisystemic demands, then, its potential depends on whether such action is an integral part of a programmatic political mass movement for systemic change. If this is the case, direct action is an indispensable part (together with some of the activities which today form part of 'lifestyle' strategies and contesting local elections) of the transitional strategy and could 
play a significant role in bringing about systemic change by creating the conditions of the daily political struggle for an inclusive democracy. But, if such action is not part of such a political project and movement, its potential as an educational tool is nil, given its exclusively negative character. This is, for instance, the case of the antisystemic currents within the antiglobalisation 'movement' which can only define what they are against but cannot make any coherent proposal about what they are in favour of replacing neoliberal globalisation and the market economy with, alienating as a result many sympathisers among the general public.

Direct action alone, and the inevitable state repression that usually accompanies it, can never lead to the 'revolutionisation' of a movement and the 'spontaneous'creation of the analysis needed for the present situation, complete

with a clear vision of the structure of future society, the transitional strategy etcalthough of course this does not mean that the liberatory project has to be 'scientified' yet again! $!^{72}$. This is a clearly romantic and historically false view about how societies change that puts us back to the period before people discovered, some hundred and fifty years ago, that organised antisystemic movements are needed to replace a system and that the majority of the population should have developed a clear antisystemic consciousness, through actually living within the institutions of a new society, before the actual transition to it takes place. History has taught us that this is the only way to avoid another totalitarian experiment.

It is therefore clear that neither direct action nor life-style anarchism/ anarchy in action could, by themselves, lead to systemic change, or even create the mass consciousness for it, unless (I will repeating it yet again!) such activities are part of a programmatic political movement for systemic change, with its own analysis of the present crisis, clear goals about a future society and a comprehensive transitional strategy leading to it. Such a project could be based, as the Inclusive Democracy project proposes, on a synthesis of the libertarian socialist and democratic traditions with the radical currents within the 'new' social movements (green, feminist etc) aiming at re-integrating society with economy, polity and nature in the form of an 'inclusive' democracy. But, what form should a new antisystemic movement for the realisation of such a project take?

\section{The transitional strategy of the ID project}

Starting point in this approach is that the world, at the beginning of the new millennium, faces a multi-dimensional crisis (economic, ecological, social, cultural and political) which is caused by the concentration of power in the hands of various elites, as a result of the establishment, in the last couple of centuries, of the system of market economy, representative 'democracy' and the related forms of hierarchical structure. If we 
accept this premise, then the obvious way out of this crisis is the abolition of power structures and relations, i.e. the creation of conditions of equal distribution of power among citizens. One way that could bring about this sort of society is strategy proposed by the Inclusive Democracy ${ }^{73}$ project, which involves the creation of political, economic and social structures that secure direct democracy, economic democracy, ecological democracy and democracy in the social realm. It also involves the creation of a new social paradigm, which, for the reproduction of inclusive democracy to be secured, has to become dominant.

Furthermore, the Inclusive Democracy project offers not only a meaningful and realistic way out of the present multidimensional crisis, but also a way of building a new globalisation, which is based on really democratic structures. The creation of a new world order based on an inclusive democracy involves the building of confederations of local, regional and national inclusive democracies. This will lead to a globalisation which will not be based on the unequal distribution of power and the domination of human being over human being and Nature, as under the present globalisation, but on the equal distribution of all forms of power between autonomous human beings and the elimination of all forms of domination. It will also be founded on a sustainable economic system which meets the basic needs of the planet's population, through a mechanism of allocation of resources between the confederations, within a planetary confederal plan of allocation of resources. Finally, meeting the non-basic needs would be determined at the local level, in a way that secures freedom of choice, whereas exchanges of surpluses between confederations would be arranged through multilateral agreements.

\section{A long-term strategy for a confederal inclusive democracy}

The project for an inclusive democracy offers not only a realistic vision of an alternative society, really missing today after the collapse of statist socialism, but also a long-term strategy and a short-term programme that will lead us to this society. ${ }^{74}$

Thus, the ID strategy involves the building of a mass programmatic political movement, like the old socialist movement, with an unashamedly universalist goal to change society along genuine democratic lines, beginning here and now. Therefore, such a movement should explicitly aim at a systemic change, as well as at a parallel change in our value systems. This strategy would entail the gradual involvement of increasing numbers of people in a new kind of politics and the parallel shifting of economic resources (labour, capital, land) away from the market economy. The aim of such a strategy should be to create changes in the institutional framework, as well as to value systems, which, after a period of tension between the new institutions and the state, would, at some stage, replace the market economy, representative 'democracy', and the social paradigm "justifying" them, with an inclusive democracy and a new democratic paradigm respectively. 
The rationale behind this strategy is that, as systemic change requires a rupture with the past, which extends to both the institutional and the cultural level, such a rupture is only possible through the development of a new political organisation and a new comprehensive political program for systemic change that will create a clear anti-systemic consciousness at a massive scale. This is in contrast to the statist socialist strategy which ends up with the creation of a clear anti-systemic consciousness only with respect to an avant-garde, or to the life-style activities which, if they create any antisystemic consciousness at all, it is restricted to the few members of various libertarian 'groupuscules'. However, the creation of a new culture, which has to become hegemonic before the transition to an inclusive democracy could be effected, is only possible through the parallel building of new political and economic institutions at a significant social scale. In other words, it is only through action to build such institutions that a mass political movement with a democratic consciousness can be built. Such a strategy creates the conditions for the transition, both the 'subjective' ones, in terms of helping the development of a new democratic consciousness and the 'objective' ones, in terms of creating the new institutions which will form the basis of an inclusive democracy. At the same time, the establishment of these new institutions will crucially assist here and now the victims of the concentration of power which is associated with the present institutional framework and particularly the victims of neoliberal globalisation to deal with the problems created by it.

Thus, people who today are alienated from all forms of power, particularly political and economic power, would have every incentive to be involved in such a movement and vote in local elections for the establishment of 'democracy in action' in their area. They will be fully aware of the fact that problems like unemployment and poverty could only be solved within the ID institutions (demotic enterprises, demotic welfare etc). They will also know that problems like air/water/food pollution could only be sorted out effectively, and at a massive social scale, if citizens start taking control of local power within the ID institutions rather than in the context of communes outside the main political and social arena. They will finally know that unless they get hold of political power at the local level and then, through confederations of local IDs, at the regional level, they will never be able to control their lives. In other words, people will be involved in a struggle for the establishment of the ID institutions not out of hunger for an abstract notion of democracy but because, through their own action, they will be able to see that the cause of all their problems (economic, social, ecological) has been due to the fact that power has been concentrated in a few hands.

The objective therefore of an ID strategy is the creation, from below, of 'popular bases of political and economic power', that is, the establishment of local inclusive democracies, which, at a later stage, will confederate in order to create the conditions for the establishment of a new confederal inclusive democracy. Therefore, a crucial element of the ID strategy is that the political and economic institutions of inclusive democracy begin to be established immediately after a significant number of people in a particular 
area have formed a base for 'democracy in action' - preferably, but not exclusively, at the massive social scale that is secured by winning in local elections under an ID program.

But, what sort of strategy can ensure the transition toward an inclusive democracy? A general guiding principle in selecting an appropriate transitional strategy is consistency between means and ends. Obviously, a strategy aiming at an inclusive democracy cannot be achieved through the use of oligarchic political practices, or individualistic activities. Furthermore, as we have seen above, it should not be restricted to the fight against the present system but it should also 'prefigure' the future one.

Thus, as regards the the fight against the present system, I think there should be no hesitation in supporting all those struggles which can assist in making clear the repressive nature of statist democracy and the market economy, i.e. all types of collective action in the form of class conflicts between the victims of the internationalised market economy and the ruling elites, or the transnational elite which 'manages' the internationalised market economy, However, the systemic nature of the causes of such conflicts should be stressed at each step and this task can obviously not be left to the bureaucratic leaderships of trade unions and other traditional organisations. This is the task of workplace assemblies that form an integral part of a movement towards an inclusive democracy, which could confederate and take part in such struggles, as part of a broader democratic movement which is based on demoi and their confederal structures. Also, activists participating in the ID movement should obviously take part in direct action activities against neoliberal globalisation, or against the serious undermining of political freedoms that has been institutionalised under the pretext of the 'war against terrorism', in alliance with other radical antisystemic groups --provided of course that, in doing so, they express the ID problematique and raise the demands which are consistent with it.

Similarly, as regards 'prefiguring' the future system, activities like Community Economic Development projects, self-managed factories, housing associations, LETS schemes, communes, self-managed farms and so on should also be supported --provided however, again, that they form part of a programmatic political movement with clear goals, means and strategies for systemic change, like the ID movement.

\section{The significance of local elections}

Contesting local elections does provide the most effective means to massively publicise a programme for an inclusive democracy, as well as the opportunity to initiate its immediate implementation on a significant social scale. In other words, contesting local elections is not just an educational exercise but also an expression of the belief that it is only at the local level that direct and economic democracy can be founded today, although of course local inclusive democracies have to be confederated to ensure the transition to a confederal democracy. It is because the demos is the fundamental social and economic 
unit of a future democratic society that we have to start from the local level to change society.Therefore, participation in local elections is an important part of the strategy to gain power, in order to dismantle it immediately afterwards, by substituting the decisiontaking role of the assemblies for that of the local authorities, the day after the election has been won. Furthermore, contesting local elections gives the chance to start changing society from below, something that is the only democratic strategy, as against the statist approaches that aim to change society from above through the conquest of state power, and the 'civil society' approaches that do not aim at a systemic change at all.

However, the main aim of direct action, as well as of the participation in local elections, is not just the conquest of power but the rupture of the socialisation process and therefore the creation of a democratic majority 'from below", which will legitimise the new structures of inclusive democracy. Given this aim, it is obvious that participation in national elections is a singularly inappropriate means to this end, since, even if the movement for an inclusive democracy does win a national election, this will inevitably set in motion a process of 'revolution from above'. This is because the rupture in the socialisation process can only be gradual and in continuous interaction with the phased implementation of the program for the inclusive democracy, which, for the reasons mentioned above, should always start at the local level. On the other hand, an attempt to implement the new project through the conquest of power at the national level does not offer any opportunity for such an interaction between theory and practice and for the required homogenisation of consciousness with respect to the need for systemic change.

If there is one lesson History taught us, this is that the basic cause of failure of previous, revolutionary or reformist, attempts aiming at a systemic change was exactly the significant unevenness in the level of consciousness, in other words, the fact that all past revolutions had taken place in an environment where only a minority of the population had broken with the dominant social paradigm. This gave the golden opportunity to various elites to turn one section of the people against another (e.g. Chile), or led to the development of authoritarian structures for the protection of the revolution (e.g. French or Russian revolutions), frustrating any attempt for the creation of structures of equal distribution of power. However, for a revolution, to be truly successful, a rupture with the past is presupposed, both at the subjective level of consciousness and at the institutional level. Still, when a revolution in the past was 'from above', it had a good chance to achieve its first aim, to abolish state power and establish its own power, but, exactly because it was a revolution from above, with its own hierarchical structures etc, it had no chance to change the dominant social paradigm but only formally, i.e. at the level of the official (compulsory) ideology. On the other hand, although the revolution from below has always been the correct approach to convert people democratically to the new social paradigm, it suffered in the past from the fact that the uneven development of consciousness among the population did not allow revolutionaries to achieve even their very first aim of abolishing state power. Therefore, the major problem with systemic change has always been how it could be brought about, from below, but by a majority of 
the population, so that a democratic abolition of power structures could become feasible. It is hoped that the ID strategy does offer a solution to this crucial problem .

Thus, once the institutions of Inclusive Democracy begin to be installed, and people, for the first time in their lives, start obtaining real power to determine their own fate, then the gradual erosion of the dominant social paradigm and of the present institutional framework will be set in motion. A new popular power base will be created. Town by town, city by city, region by region will be taken away from the effective control of the market economy and statist forms of organisation (national or international), their political and economic structures being replaced by the confederations of democratically run communities. An alternative social paradigm will become hegemonic and the break in the socialisation process--the precondition for a change in the institution of society--will follow. A dual power in tension with the statist forms of organisation will be created which ultimately may or may not lead to confrontation with the ruling elites depending on the balance of power that would have developed by then. Clearly, the greater the appeal of the new institutions to citizens the smaller the chance that the ruling elites will resort to violence to restore the power of the state and the market economy institutions, on which their own power rests.

\section{The emancipatory subject in neoliberal modernity}

\section{The need for a new type of movement}

Today, as I attempted to show elsewhere, ${ }^{75}$ we face the end of 'traditional' antisystemic movements : the issue is not anymore to challenge one form of power or another but to challenge power itself, in the sense of its unequal distribution that constitutes the basis of heteronomy. In other words, what is needed today is a new type of antisystemic movement which should challenge heteronomy itself, rather than simply various forms of heteronomy, as used to be the case in 'traditional' antisystemic movements challenging the unequal distribution of economic power (statist socialist movements), political power (libertarian socialist), or social power (feminist etc) as the basis of all other forms of power. Therefore, the issue is to challenge the inequality in the distribution of every form of power, in other words, power relations and structures themselves.

It is this collapse of the traditional antisystemic movements which raises the need for a new type of antisystemic movement.A second reason which is related to the first one and justifies further the need for such a movement is the fact that today we face not simply the end of the traditional antisystemic movements but also of traditional Marxist class divisions. However, the fact that we face today the end of class politics does not 
mean that there is no 'system' anymore as such, or 'class divisions' for that matter. What it does mean is that today we face new 'class divisions' ${ }^{76}$ Thus, in the ID problematique, the phasing out of economic classes in the Marxist sense simply signifies the death of traditional class divisions and the birth of new 'holistic' class divisions, i.e. divisions which are located into the power structures of the socio-economic system itself and not just to some aspects of it, like economic relations alone, or alternatively gender relations, identity politics, values and so on. In other words, the present social divisions between dominant and subordinate social groups in the political sphere (professional politicians versus the rest of citizenry), the economic sphere (company owners, directors, managers versus workers, clerks etc) and the broader social sphere (men versus women, blacks versus whites, ethnic majorities versus minorities and so on) are based on institutional structures that reproduce an unequal distribution of power and on the corresponding cultures and ideologies, (i.e. the 'dominant social paradigm').

In today's society, the main structures which institutionalise the unequal distribution of power are the market economy and representative democracy, although other structures which institutionalise the unequal distribution of power between sexes, races, ethnicities etc cannot just be 'reduced' to these two main structures. So, the replacement of these structures by institutions securing the equal distribution of political, economic and social power within an inclusive democracy is the necessary condition (though not the sufficient one) for the creation of a new culture that would eliminate the unequal distribution of power between all human beings, irrespective of sex, race, ethnicity etc. Therefore, the attempt by Greens, feminists and other supporters of the politics of difference and identity to change culture and values first, as a way of changing some of the existing power structures, (rather than being engaged in a fight to replace all the structures which reproduce the unequal distribution of power and, within this struggle, create the values that would support the new structures), is doomed to marginalisation and failure, with (at best) some reforms being achieved on the way.

It is therefore clear that, although it is not meaningful to talk anymore about monolithic class divisions, this does not rule out the possibility that, when the social groups which belong to the emancipatory subject as defined below develop a shared consciousness about the values and institutions which create and reproduce structures of unequal distribution of power, they may unite, primarily, not against the dominant social groups as such but against the hierarchical institutional framework and those defending it. The unifying element which may unite members of the subordinate social groups around a liberatory project like the ID project is their exclusion from various forms of power-an exclusion which is founded on the unequal distribution of power that today's institutions and the corresponding values establish. This brings us to the crucial question facing any transitional strategy: the 'identity' of the emancipatory subject, or as it used to be called the 'revolutionary subject'. 
All antisystemic strategies in the past were based on the assumption that the revolutionary subject is identified with the proletariat, although in the last century several variations of this approach were suggested to include in the revolutionary subject peasants ${ }^{77}$ and later on students. ${ }^{78}$ However, the 'systemic changes' that marked the shift from statist modernity to neoliberal modernity and the associated class structure changes, as well as the parallel ideological crisis, ${ }^{79}$ meant the end of traditional class divisions, as I mentioned above -although not the end of class divisions as such-- as social-liberals suggest. ${ }^{80}$ Still, some in the radical Left, despite the obvious systemic changes, insist on reproducing the myth of the revolutionary working class, usually by redefining it in sometimes tautological ways. ${ }^{81}$ At the same time, writers on the libertarian Left like Bookchin $^{82}$ and Castoriadis ${ }^{83}$ moved to a position according to which, in defining the emancipatory subject, we have to abandon any 'objective criteria' and assume that the whole of the population ('the people') is just open-or closed-to a revolutionary outlook. Finally, postmodernists replace class divisions with identity differences and substitute fragmentation and difference for the 'political system'. This has inevitably led to a situation where the systemic unity of capitalism, or its very existence as a social system, is denied and instead of the universalist aspirations of socialism and the integrative politics of the struggle against class exploitation, we have a plurality of essentially disconnected particular struggles which ends in a submission to capitalism' ${ }^{84}$

In the ID problematique, what we need today is a new paradigm which, while recognising the different identities of the social groups which constitute various subtotalities (women, ethnic minorities etc), at the same time acknowledges the existence of an overall socio-economic system that secures the concentration of power at the hands of various elites and dominant social groups within society as a whole. Such a paradigm is the Inclusive Democracy paradigm which does respond to the present multiplicity of social relations (gender, ethnicity, race, and so on) with complex concepts of equality in the distribution of all forms of power that acknowledge people's different needs and experiences. In fact, the main problem in emancipatory politics today is how all the social groups, which potentially form the basis of a new emancipatory subject, would be united by a common worldview, a common paradigm, which sees the ultimate cause of the present multidimensional crisis in the present structures that secure the concentration of power at all levels, as well as the corresponding value systems. In this problematique, given the broad perspective of the project for an inclusive democracy, a new movement aiming at an inclusive democracy should appeal to almost all sections of society, apart of course from the dominant social groups, i.e. the ruling elites and the overclass.

Thus, the economic democracy component of the ID project should primarily appeal to the main victims of the internationalised market economy, i.e. the underclass and the marginalized (the unemployed, blue collar workers, low-waged white collar workers, part-timers, occasional workers, farmers who are phased out because of the expansion of agribusiness), as well as the students, the prospective members of the 
professional middle classes, who see their dreams for job security disappearing fast in the 'flexible' labour markets being built. It should also appeal to a significant part of the new middle class which, unable to join the 'overclass', lives under conditions of constant insecurity, particularly in countries of the South as the Argentinian crisis showed .

The political democracy component of the ID project should appeal to all those who are presently involved in local, single-issue movements for the lack of anything better. As even the theoreticians of socialliberalism recognise, although confidence in professional politicians and government institutions is in drastic decline, the decay of parliamentary politics is not the same thing as depoliticisation. This is obvious by the parallel growth of new social movements, NGOs, citizens' initiatives etc. No wonder that the 'small group movement' (i.e. small numbers of people meeting regularly to promote their common interest) is thriving with 40 percent of the population in the USA-some 75 million Americans - belonging to at least one small group, while in the UK self-help and environmental groups have in recent years expanded rapidly. ${ }^{85}$ Although this celebrated expansion of the 'civil society' is concentrated in the new middle class, still, this is an indication of a thirst for a genuine democracy in which everybody counts in the decisiontaking process. Furthermore, given that the scope for citizen participation is presently restricted to single issues, it is not surprising that it is single issue movements and organisations which flourish. In other words, one may argue that the expansion of the small group movement indicates, in fact, a move from pseudo-democracy at the national level--in which the system of representation nullifies collective participation-- to pseudodemocracy at the local level--in which important political and economic decisions are still left to the political and economic elites but at the same time, in a kind of 'sub-politics', citizen bodies in the 'active' civil society claim a right to take decisions on side issues,or local issues.

Finally, the ecological component of the ID project, as well as the one related to 'democracy at the social realm', should appeal to all those concerned about the effects of concentration of power on the environment and to those oppressed by the patriarchal and other hierarchical structures in today's society. ${ }^{86}$

So, to sum it up, it is necessary that the new political organisation is founded on the broadest political base possible. To my mind, this means a broad spectrum of radical activists, involving antiglobalisation activists, radical ecologists, supporters of the autonomy project, libertarian socialists, radical feminists, libertarian leftists and every other activist that adopts the democratic project. The ID project should appeal to all those radical activists given its broad social appeal to the vast majority of the population. Thus, the following social groups could potentially be the basis of a new 'liberatory subject' for systemic change:

- the victims of the market economy system in its present internationalised form, i.e. the unemployed, low-waged, farmers under extinction, occasionally employed etc; 
- those citizens, particularly in the 'middle groups', who are alienated by the present statecraft which passes as "politics" and already claim a right of self-determination through the various local community groups;

- workers, clerks etc who are exploited and alienated by the hierarchical structures at the workplace;

- women, who are alienated by the hierarchical structures both at home and the workplace and yearn for a democratised family based on equality, mutual respect, autonomy, sharing of decision-making and responsibilities, emotional and sexual equality

- ethnic or racial minorities, which are alienated by a discriminatory 'statist' democracy that divides the population into first and second class citizens

- all those concerned about the destruction of the environment and the accelerating deterioration in the quality of life, who are presently organised in reformist ecological movements, marginalized eco-communes etc

There is no doubt that several of these groups may see at the moment their goals as conflicting with those of other groups (middle groups vis-à-vis the groups of the victims of the internationalised market economy and so on). However, as I mentioned above, the ID project does offer a common paradigm consisting of an analysis of the causes of the present multidimensional crisis in terms of the present structures that secure the unequal distribution of power and the corresponding values, as well as the ends and means that would lead us to an alternative society. Therefore, the fight to build a movement inspired by this paradigm, which to be successful has to become an international movement, is urgent as well as imperative, so that the various social groups which form the new liberatory subject could function as the catalyst for a new society that would reintegrate society with polity and the economy, humans and Nature.

\section{A new type of politics and political organisation}

\section{A new type of Politics}

Old politics is doomed, as the accelerating internationalisation of the market economy is met by the continuous decline of representative 'democracy'. The impotency of the state to effectively control the market forces, in order to tackle the fundamental problems of massive unemployment, poverty, rising concentration of income and wealth and the continuing destruction of the environment, has led to massive political apathy and 
cynicism, particularly among the underclass and the marginalized. As a result, all parties today compete for the vote of the middle classes which, effectively, determine the political process. At the same time, the pipe dreams of some parts of the 'left' for a democratisation of the civil society are, also, doomed. As I mentioned above, the internationalisation of the market economy is being inevitably followed by the internationalisation of the civil society. In other words, competition imposes the least common denominator standards as far as social and ecological controls on markets is concerned. Therefore, that type of civil society is bound to prevail which is consistent with the degree of marketisation that characterises the most competitive parts of the global economy.

It is therefore clear that we need a new type of politics which would comprise the creation of local inclusive democracies, i.e. the creation of a new public realm that would involve citizens as citizens aking decisions on broad political, economic and social matters within the institutional framework of demotic assemblies; citizens as workers taking decisions on the running of demotic enterprises within the institutional framework of workplace assemblies; citizens as students taking decisions on the running of colleges and schools etc.This new Politics requires a new type of political organisation which will play the role of the catalyst for its emergence. So, what form should this new political organisation take and how can we go about to create it?

\section{A new type of political organisation}

It is clear that the new type of political organisation should itself mirror the desired structure of society. This would not be the usual political party, but a form of 'democracy in action', which would undertake various forms of intervention at the local level, always as part of a comprehensive program for social transformation aiming at the eventual change of each local authority into an inclusive democracy. These forms of intervention should extend to every area of the broadly defined above public realm and should involve:

. At the political level, the creation of 'shadow' political institutions based on direct democracy, (neighbourhood assemblies, etc) as well as various forms of direct action (marches, rallies, teach-ins and civil disobedience) against the existing political institutions and their activities;

- At the economic level, the establishment of a 'demotic' sector, (i.e. a sector involving demotic production units which are owned and controlled collectively by the citizens, demotic welfare etc) as well as various forms of direct action against the existing economic institutions and their activities;

- At the social level, the creation of self-governing institutions in the workplace, the place of education etc, as well as participating in struggles for worker's democracy, household democracy, democracy in the educational institutions and so on; 
- At the ecological level, the establishment of ecologically sound production and consumption units, as well as direct action against the corporate destruction of Nature;

- At the cultural level, activities aiming at the creation of a community-controlled art (in place of the presently elite-controlled art activities) and alternative media activities that will help in making the value system which is consistent with an inclusive democracy the hegemonic culture in society.

The following is a general description of the steps that might be taken in building an ID organisation, although of course the concrete form that this procedure will take in practice will crucially depend on local conditions and practices.

The first step in building such an organisation might be to initiate a meeting of a number of people in a particular area who are interested in the ID project with the aim to create a study group for the discussion of this project. After a series of meetings between the people involved, and as a result of discussions on the matter, a set of 'non-negotiable' principles expressing the aims of the group with respect to the goal of Inclusive Democracy might be formulated. This minimum program should express the basic goals, means and strategy of the ID group. ${ }^{87}$ The group should also formulate its organisational structure along non-hierarchical lines, as well as its decision-taking process on the basis of direct democracy principles.

The next step might be the publication of a local newsletter, or in the case of big cities a local magazine, in which this minimum program would be published, as well as comments on local or national/international news from the ID perspective and brief theoretical texts on the goals, means, strategy of the ID project. News on relevant, local or not, activities should get particular prominence. At this stage, the ID group could begin getting involved in the organisation of public meetings in which issues of particular concern to the local people (economic, ecological, social etc) are discussed. All these issues should be introduced by members of the group who express the ID angle and full discussions with local citizens should follow.

As the number of people involved in the ID group grows, it may start taking part in local struggles (or even initiate such struggles on various issues of concern for the establishment of an ID) and also --in alliance with similar groups from other areas-- in struggles on regional, national or international issues. With this aim, the group should liaise with similar local groups in the same region, country and other countries to form confederations of autonomous ID groups (at the regional, national and international levels) for the exchange of information, organisation of struggles, public meetings etc. The creation of an ID electronic newsletter might play a significant role in this process. Alliances with other radical groups of the Left should also be encouraged on specific issues (e.g. to replace the present European Union of capitalists with a European 
Community of peoples) on which a consensus view on the demands to be raised could be reached.

Finally, once a sufficient number of activists has joined the group so that it can take the form of an ID political organisation (with organisational structure and decisiontaking process similar to the ones of the original group) the ID organisation may start expanding its activities and be involved in the creation of local institutions of political, and economic democracy as well as democracy in the social realm (workplace, educational place etc), cultural activities etc - see below. At the same time the ID organisation should start contesting local elections, Initially, with an educational aim, i.e. to familiarise citizens on a significant social scale about the ID poject. Once however the ID organisation has won the elections in a particular area it should start implementing the transitional program for the building of an inclusive democracy. Needless to add that in all these stages the activists in the ID movement function not as 'party cadres' but as catalysts for the setting up of the new institutions. In other words, their commitment is to the democratic institutions themselves and not to the political organisation.

\section{The Transition to an inclusive democracy}

A New World Order based on an inclusive democracy is a form of social organisation that re-integrates society with economy, polity and nature within an institutional framework that secures the necessary conditions for the equal distribution of all forms of power. This involves the creation of institutions of:

- political democracy (direct democracy), which are based on processes securing that all political decisions (including those relating to the formation and execution of laws) are taken by the citizen body (the demos) collectively and without representation, as well as on structures institutionalising the equal distribution of political power

- economic democracy, in which the demoi control the economic process, within an institutional framework of demotic ownership and control of the means of production and distribution, beyond the confines of the market economy and state planning

- Democracy in the social realm, in which all public realm institutions in which collective decisions can be taken (e.g. workplaces, educational places, cultural institutions et.c) are self-governed under the overall control of the demoi, whereas personal relations are based on a value system which is compatible with the overall democratic institutions of society, i.e. a value system based on the principles of 
individual and social autonomy and solidarity that rules out any form of domination based on sex, race, ethnicity, cultural differences and so on

- Ecological Democracy, in which the ID institutional framework and the value system which is compatible with it secure the necessary conditions for the reintegration of society and nature.

Therefore, the transition to an inclusive democracy should include steps to move society towards each of the above components of it. The local ID groups/organisation should formulate a comprehensive program for social change which would elaborate for their area the overall objective to create a different form of social organisation, based on an inclusive democracy. In other words, the program should make absolutely clear that the ultimate objective of the various projects included in it is the replacement of the present oligarchic structure with an inclusive democracy, as defined above. This implies that such a program should be fought for not just as a kind of new politics but as the political structure itself leading to an inclusive democracy.

\section{Transition to political democracy}

The programme for the transition to an inclusive democracy that the local ID groups/organisation will formulate, starting from demands that mobilise people around their immediate concerns, should have the following basic aims:

a) to develop an 'alternative consciousness' as regards methods of solving the political, economic, social and ecological problems in a democratic way. It should therefore connect today's multidimensional crisis to the present socio-economic system and the need to replace it with a confederal inclusive democracy; and

b) to make proposals on how to start building the political, economic and social institutions themselves that would lead to an inclusive democracy. It should therefore propose measures that could lead both to greater political and economic self-reliance and to democratic procedures in taking decisions affecting the citizens' life.

Concerning to (a), that is, the aim of creating an alternative consciousness, the program should stress why representative 'democracy' has nothing to do with the original meaning of democracy and was in fact an American invention whose real aim was the dilution of popular power ${ }^{88}$. In representative 'democracy' people abdicate their power to elected (with the massive help of the economic elite and the controlled by it mass media) professional politicians who are committed to a few vague generalities (as regards the people) but to specific policies (as regards the economic elite which effectively elects them). The only 'power' given to the people in such a system is to change every four years 
or so one gang of professional politicians with another to carry out the same in effect policies, particularly in today's system of neoliberal globalisation when even the old differences between political parties have effectively disappeared. As the May 1968 graffiti summarised representative 'democracy': 'it is painful to submit to our bosses; it is even more stupid to choose them!'

The program should show that not only political alienation but also problems like unemployment, poverty and work alienation, as well as poor quality of life, pollution and environmental destruction, and problems of gender/race etc discrimination and cultural homogenisation are all connected to a system based on the concentration of political, economic and social power in the hands of elites that represent a very small proportion of the population. The relationship of each of the main institutions of society to these problems should be particularly stressed. Thus, it should be shown for instance that the market allocation of resources eads to maldevelopment, unemployment and poverty; the private ownership of productive resources does not allow any economic democracy to flourish but instead leads to economic and political oligarchy, the alienation of the vast majority of people with respect to their jobs, as well as the perpetuation of inequality; and the hierarchical organisation of society, both at the 'macro' level (state) and the 'micro' level (hierarchical relations at work, family, school, etc.) is incompatible with democracy in the social realm, autonomy and freedom.

Thus, a comprehensive program for social change should make clear that, contrary to what the reformist Left suggests, the way out of the present multidimensional crisis is not by forcing the state to fight corporate interests but by creating a new public realm, a new pole of power, that would fight both the corporate interest and the state, i.e. both the market economy and representative 'democracy'. Then, citizens, for the first time in their lives, will have a real power in determining the affairs, albeit partially at the beginning, of their own community. All this, in contrast to today's state of affairs when citizens supposedly have the power, every four years or so, to change the party in government but, in effect, they are given neither any real choice nor any way of imposing their will on professional politicians or economic elites. This becomes obvious, for instance, if one looks at the electoral programs of national parties, which are expressed in such broad and vague terms that they do not commit politicians to anything concrete.

As regards (b) the proposals on alternative political institutions, the ID groups/organisation, even before they have taken over power and established a demos in their area, but after they have become widely known locally (something that presupposes that they have already begun contesting local elections) should take various initiatives towards the establishment of a political (direct) democracy, such as:

- the organisation of demotic assemblies to discuss important local issues. In large cities these assemblies could take the form of neighbourhood assemblies that would confederate and form the 'city-confederal assembly' out of delegates from each neighbourhood assembly. This confederal assembly would simply carry out 
the decisions of neighbourhood assemblies and take complementary decisions for the implementation of such decisions. In other words, the fundamental principle has to be established that it is actually the demotic assemblies that take decisions and the delegates in confederal assemblies never 'represent' citizens and formulate policies 'on their behalf'. Delegates to the city-confederal assembly may be elected on rotation basis but they have to be immediately recallable by the neighbourhood assemblies through the democratic procedures that they will establish. At this stage, the ID groups/organisation may also demand the official recognition of these citizens' assemblies by the town/city council, as well as the assigning of specific powers to them.

- the election of a 'shadow town/city council', i.e. of a council that will 'shadow' the activities of the official town/city council and make alternative proposals on its agenda. The shadow council will consist of delegates from the demotic assemblies and will make proposals on the basis of the general principles discussed in the assemblies. The same principles that apply on the election/recall of delegates to the confederal assembly would apply here.

- the demand and fight for the greatest possible decentralisation of political power, as well as economic power (taxing/spending power etc) to the local level, given that decentralisation is the basis of organisation of an inclusive democracy. However, it should be stressed that all these steps, as well as those described below, do not aim to achieve some sort of reform of the existing institutions of political and economic power, i.e. the system of the market economy and parliamentary 'democracy'. This is why each 'transitional' demand (e.g. for greater decentralisation) should be accompanied by a statement by the ID groups/organisation which would connect the particular demand to the long-term goal of inclusive democracy. The ID movement is an 'antisystemic' and not a reformist movement and it will attempt to achieve all its goals through peaceful means, although at some stage it may come under violent attack by the ruling elites, in which case of course it will have to defend itself. However, the more 'hegemonic' the ID social paradigm is the more difficult it will be for the ruling elites to impose their will by force.

\section{Transition to economic democracy}

As regards the aim of building alternative economic institutions leading to economic democracy, the programme should make clear why the taking over by the ID movement of several town/city councils could create the conditions for:

a) the drastic increase of the demos' economic self-reliance; 
b) the setting up of a demotic economic sector, i.e. a sector owned by the demos; and

c) the creation of a democratic mechanism for the confederal allocation of resources.

As I have described these conditions in detail elsewhere ${ }^{89}$ I shall only summarise them here.

Concerning self-reliance first there is significant Green literature on the matter, which however suffers from the basic drawback that it is reformist i.e. it aims to reform the market economy with the aim of greater self-reliance. However, an ID movement has to develop a transitional strategy for a radical decentralisation of power to the demoi with the explicit aim of replacing the present political and economic institutional framework. Steps in this direction could be the effort (which will be made easier when local power has been won) for the increase of:

- local financial power, through the creation of Demotic Credit Unions (i.e., financial coops supported by the demos) to provide loans to their members for their personal and investment needs, as a first step in the creation of a demotic bank network; also LETS ${ }^{90}$ schemes could be introduced as a first step in the installation of a demotic currency (i.e. a currency controlled by the Demos rather than by a central bank which in turn is controlled by the ruling elites, as is the case with the US dollar and the Euro); finally, a demotic credit card scheme may be created with the aim of covering the basic needs of all citizens through the use of locally produced goods and services, as a first step for the establishment of a voucher system that would replace all currencies in an inclusive democracy.

- local tax power, through tax decentralisation, i.e. the shift of taxing power from the national to the local level. Initially, new local taxes could be complementary to state taxes but the ID movement should fight for tax decentralisation and the parallel introduction of a new demotic tax system (i.e. a tax system controlled by the demos) which could be used to: finance a program for the demoticisation of the local productive resources, providing employment opportunities for local citizens; finance a program for social spending that will cover the basic needs of all citizens; finance various institutional arrangements that will make democracy in the household effective (e.g. payment for work at home, for the care of children and the elderly etc); finance programs for the replacement of traditional energy sources with local energy resources, especially renewable energy (solar, wind, etc.); to penalise economically the anti-ecological activities of branches and subsidiaries of large corporations based in the area. So, the combined effect of the above measures will be to redistribute economic power within the community, in the sense of greater equality in the distribution of income and wealth. This, combined with the introduction of the democratic planning procedures (see below), 
should provide significant ground for the transition towards full economic democracy.

- power to determine local production, through, initially the provision of financial incentives to local producers/shops/citizens in order to induce them to produce/sell/buy locally produced goods with the aim of breaking the chains of big manufacturers/distributors. At a later stage, the creation of demotic enterprises (i.e. enterprises owned by the demos) would give the power to the demos to increasingly take over production.

- power to cover the welfare needs of local citizens through the creation of a demotic welfare system, i.e. a welfare system controlled by the demos that would provide important social services (education, health, housing, etc.) locally, or regionally in cooperation with other demoi in the area. Such a system would not only maximise the use of local productive resources but, also, drastically reduce outside dependence.

Coming next to the creation of a demotic economic sector this is a crucial step in the transition to an inclusive democracy, not only because of its importance with respect to economic democracy but also because the establishment of self-managed productive units constitutes the foundation for workplace democracy. A demotic sector would involve new collective forms of ownership that would ensure control of production, not only by those working in the production units, but also by the demos. This could be achieved through the creation of:

1) Demotic enterprises, i.e. productive units that could belong to the demos and be managed by the workers working in those units, while their technical management (marketing, planning, etc.) could be entrusted to specialised personnel. However, the overall control over such enterprises should belong to the demotic assemblies that would supervise their production, employment and environmental policies ensuring that the 'general social interest' nther than the particular interest of each demotic enterprises' employees is pursued. Such enterprises may be established even before supporters of the inclusive democracy project take over a city/town council through the use, for instance, of Land Trusts, although it will be after local power has been won that such enterprises can flourish. ${ }^{91}$ These enterprises should be clearly distinguished from both the bureaucratic socialist enterprises and the capitalist firms. This could be achieved by decentralisation of decision-making, within the framework of community-owned but independently run co-ops. Thus, the demotic assembly could determine social and ecological targets that the demotic enterprise would have to achieve whereas the enterprise itself could be run by its employees. Their survival in the transitional period would depend on how successful the new political and economic institutions are in creating a new consciousness, which will make citizens more resistant to purely financial incentives. An important step in this direction would be that 
demotic enterprises would produce exclusively for the local market, with the use of local resources. This presupposes that demotic enterprises, unlike similar Green or lifestyle activities, would be part of a comprehensive program to demoticise the economy -in other words, a program whose constituent elements are self-reliance, demotic ownership and confederal allocation of resources. The aim of this process is to gradually shift more and more human and non-human resources away from the market economy into the new 'demotic' sector of the economy that would form the basis of an inclusive democracy. At the end of this process, the demotic enterprises would control the local economy and would be integrated into the confederation of demoi, which could then buy, or expropriate, privately owned big enterprises.

2) a network of demotic bank co-operatives, similar, for example, to the very successful Basque network of the Caja Laboral Popular in Spain ${ }^{92}$, which supports the Mondragon co-ops could be established before local power has been won. But after local elections have been successfully contested in a number of cities/towns then the possibility arises for the creation of demotic bank network owned and controlled by the demos. Thus, each city/town could have its own demotic bank that could be integrated into a regional and later a confederal network that could be used: to absorb local savings so that local eco-friendly investment projects could be financed that maximise local employment; to offer other specialised services that would allow the establishment and running of demotic enterprises by any interested social group in the area, which would not necessarily possess the required specialised knowledge (e.g., workers of bankrupt companies, unemployed, lowwage people, etc.); to undertake research on the type of production units to be established in the area, on the basis of criteria which would aim at the maximisation of local employment, of local (and consequently of confederal) economic self-reliance and productivity, as well as at the minimisation of the effects on the environment; to provide specialised services on planning the production layout, designing the workplace, manpower training, accounting systems, etcetera.

Finally, as regards the transition to a Confederal Allocation of Resources, the fundamental problem that a strategy leading to a system of confederal allocation of resources faces is how to create such institutional arrangements for economic democracy that are compatible with an institutional framework that is still a market economy. As the confederal allocation of resources was described in Towards An Inclusive Democracy, ${ }^{93}$ the system involves two basic mechanisms for the allocation of resources:

a) a democratic planning mechanism for most of the macroeconomic decisions, (social autonomy element) and 
b) a voucher system for most of the micro-economic decisions, which, by replacing the real market with an artificial one, would create conditions of freedom of choice (individual autonomy element).

It is obvious that the voucher system cannot be introduced before a full economic democracy in the form of a confederation of demoi has been introduced, although steps in this direction could be taken earlier (e.g. the demotic credit card scheme mentioned above) However, a democratic planning system is feasible even in the transitional period although, obviously, its decision-making scope would be seriously constrained by the market economy. Still, such a system could play a useful role in educating people in economic democracy and at the same time in creating the preconditions for individual and social autonomy.

But, for any democratic mechanism to be significant and to attract citizens in the decision-taking process, it is presupposed that the decisions themselves are important. It is therefore crucial that during the transition to an inclusive democracy the demos should be empowered with significant powers that would convert it into a coherent system of local taxation, spending and finance. Then, demotic assemblies could be empowered to make decisions affecting the economic life of the community, which would be implemented by the Town Council or some other relevant body, af ter it has been converted into a body of recallable delegates.

Thus, the shift of tax power to the cities/towns, which should be a basic demand of an ID movement, would allow demotic assemblies to determine the amount of taxes and the way in which taxes would be charged on income, wealth, land and energy use, as well as on consumption. Demotic assemblies could, at annual intervals, meet and discuss various proposals about the level of taxation for the year to come, in relation to the way the money collected by the demos should be spent. This way, demotic assemblies would start taking over the fiscal powers of the state, as far as their demoi are concerned, although in the transitional period, until the confederation of demoi replaces the state, they would also be subject to the state fiscal powers.

Similar measures can be taken as regards the present state powers with respect to the allocation of financial resources. The introduction of a demotic banking system, in combination with demotic currencies, will give significant power to demotic assemblies to determine the allocation of financial resources in the implementation of the demos's objectives (creating new enterprises, meeting ecological targets etc.)

Finally, assemblies would have significant powers in determining the allocation of resources in the demoticised sector, namely, the demotic enterprises and the demotic welfare system. As a first step, demotic assemblies could introduce a voucher scheme with respect to social services. At a later stage, when a significant number of demoi have joined the confederation of inclusive democracies, demotic assemblies could expand the voucher 
system to cover basic needs of all citizens, initially in parallel with the market economy -until the latter is phased out.

\section{Transition to democracy in the social realm}

As I mentioned above the transitional strategy should involve steps in the development of institutions establishing a 'democracy at the social realm' (self-governing institutions in the workplace, the household, the place of education etc) and the values corresponding to it. This implies, that the ID groups, apart from participating in struggles for worker's democracy, household democracy, democracy in the educational institutions and so on, should initiate moves for the establishment of alternative institutions like the demotic enterprises, demotic clinics, schools etc, which will be self-governed as described above. Furthermore they should take steps to enhance self-government in existing institutions.

The creation of an alternative culture plays a crucial role in the process of creating a democratic Paedeia, i.e. a system of all round education which creates the character of a democratic citizen and at the same time promotes the value system that is consistent with an inclusive democracy so that it occupies a hegemonic position in society. This is a completely different system from today's system of education that constitutes a basic part of the socialisation process that produces disciplined subjects rather than free citizens. Similarly the free expression of artists--free from market or bureaucratic considerations-should be enhanced, in place of the present elite-controlled art activities

In this context, a system of alternative self-governed media should be established, even before local power has been won, with the aim to present the news from the people's rather than from the elites' point of view. The alternative media established as part of the ID program would play a crucial role in developing an 'alternative consciousness', as regards the methods of solving the economic and ecological problems in a democratic way. They should highlight the systemic nature of today's economic and ecological crisis and make proposals on how to start building the new society. Once local power has been won, such alternative media should be converted into demotic media that will be under the overall control of the demotic assemblies.

In sum, a new culture for a democratic society should be promoted that will be characterised by very different values than those of a market economy. The values of heteronomy, competition, individualism and consumerism which are dominant today have to be replaced in a democratic society by the values of individual and collective autonomy, co-operation, mutual aid, solidarity and sharing. 


\section{Transition to ecological democracy}

Finally, the transitional strategy should involve steps in the development of institutions and values which aim at the reintegration of society with Nature and the elimination of any human attempt to dominate the natural world. This implies, apart from participating in struggles against the activities of the political and economic elites which have resulted in the present ecological crisis, the initiation of moves for the establishment of alternative 'eco-friendly' institutions and renewable forms of energy. In fact, as I showed elsewhere ${ }^{94}$ the establishment of the new political and economic institutions itself and particularly the drastic decentralisation that the new institutions involve is a crucial step in this direction, as it allows the development of new lifestyles, new patterns of work, production, energy use and consumption, which are perfectly compatible with the aim of an ecological democracy.

In conclusion, no one should have any illusions that the establishment of democracy will be a swift process or that the implementation of a transitional strategy program will not have a hard time from the elites controlling the state machine and the market economy. This process is bound to be a long one involving a huge popular movement and will extend over an entire historical period. However, without underestimating the difficulties involved in the context of today's perfected methods of brain control and economic violence, which, in fact, might prove more effective methods than pure state violence in suppressing a movement for an inclusive democracy, I think that the proposed strategy is a realistic strategy on the way to a new society.

* Editor, Democracy and Nature.

\section{Notes}

${ }^{1}$ See Takis Fotopoulos, 'The Myth of Postmodernity', Democracy \& Nature, vol 7 no 1 (March 2001) pp 27-76.

2 Takis Fotopoulos, 'The end of traditional antisystemic movements and the need for a new type of antisystemic movement today', Democracy \& Nature, vol 7 no 3 (November 2001) pp 415 -456.

${ }^{3}$ Anti-systemic social divisions are defined as those social divisions which explicitly or implicitly challenge the legitimacy of a hierarchical system that creates and reproduces the unequal distribution of power see $\mathrm{T}$. Fotopoulos, 'Class Divisions Today-the Inclusive Democracy Approach', Democracy \& Nature, vol 6 no 2 (July 2000) pp. 211-252.

${ }^{4}$ Leszek Kolakowski, Main Currents of Marxism, (Oxford: Oxford University Press, 1978) vol 2, pp. 109110.

${ }^{5}$ See Takis Fotopoulos, Towards An Inclusive Democracy, (London/NY: Cassell/Continuun, 1997) Chs 1 \& 2.

${ }^{6}$ See Takis Fotopoulos, Towards An Inclusive Democracy, CHs $1 \& 4$.

${ }^{7}$ T. Fotopoulos, 'Welfare state or economic democracy? Democracy \& Nature, vol 5 no 3 (November 1999), pp. 433-468.

See Alex Callinicos' interview for the Greek daily Eleftherotypia, 1 October 2000. 


\footnotetext{
${ }^{9}$ See Takis Fotopoulos, Towards An Inclusive Democracy, pp. 85-100.

${ }^{10}$ See Takis Fotopoulos, Towards An Inclusive Democracy, pp.158-64.

11 Takis Fotopoulos, Towards An Inclusive Democracy Ch 2; see also, M. Olson, The Rise and Decline of Nations (New Haven, Connecticut: Yale University Press, 1988).

12 See Takis Fotopoulos, 'The Myth of Postmodernity', and 'The end of traditional antisystemic movements'.

${ }^{13}$ See the 'Interview with Murray Bookchin', by David Vanek, Harbinger, A Journ al of Social Ecology, vol 2 no1, 2000 http://www.social-ecology.org/harbinger.

${ }^{14}$ Takis Fotopoulos, 'Globalisation, the reformist Left and the anti-globalisation movement', Democracy \& Nature, vol 7 no 2, pp. 233-280.

${ }^{15}$ See Takis Fotopoulos, 'The Myth of Postmodernity'.

${ }^{16}$ Simon Tormey 'Post-Marxism, Democracy and the Future of Radical Politics', Democracy \& Nature, vol 7 no 1 (March 2001) pp. 119-134. A similar proposal is made by Best and Kellner who advocate a politics of alliance and solidarity that builds on both modern and postmodern traditions based on coalitions and multifront struggle. (Steven Best and Douglas Kellner, 'Dawns, Twilights, and Transitions: Postmodern Theories, Politics, and Challenges', Democracy \& Nature, vol 7 no 1 (March 2001) pp. 101-118.

${ }^{17}$ See Fotopoulos, 'Class Divisions Today-The Inclusive Democracy Approach'.

${ }^{18}$ See Fotopoulos, Antisystemic movements.

${ }^{19}$ See Fotopoulos, Towards An Inclusive Democracy, pp. 198-99.

${ }^{20}$ See Fotopoulos, Towards An Inclusive Democracy, pp. 316-328.

21 ibid. p. 322.

${ }^{22}$ Leszek Kolakowski, Main Currents of Marxism, (Oxford: Oxford University Press, 1981) vol 2, p. 53.

${ }^{23}$ See e.g. Leszek Kolakowski, Main Currents of Marxism, (Oxford: Oxford University Press, 1981) vol 3. p. 244.

${ }^{24}$ Vladimir Lenin, What Is to Be Done? (Moscow: Progress Publishers, 1967) cf. pp. 30-32.

${ }^{25}$ H. Marcuse, Soviet Marxism, (London: Routledge, 1958), p. 147.

${ }^{26}$ Herbert Marcuse, Soviet Marxism p. 145.

${ }^{27}$ See Takis Fotopoulos, Towards An Inclusive Democracy, Ch 2.

${ }_{28}^{28}$ Che Guevara, Guerrilla Strategy, (New York: Monthly Review Press, 1967), p. 15.

29 ibid. See, also, for the case of urban guerrilla warfare, Carlos Marighela, For the liberation of Brazil (London: Pelican, 1971).

${ }^{30}$ See on the transnational elite concept Fotopoulos 'Globalisation'.

31 Iain Watson. 'An examination of the Zapatista Army of National Liberation (EZLN) and new political participation' (in this issue).

${ }^{32}$ Marianne Duran de Huerta and Nick Higgins,' Interview With Zapatista Leader subcommandante Marcos', International Affairs 75, (April, 1999) pp. 269-281.

${ }^{33}$ Alexandros Gezerlis. 'Latin America: Popular Movements in Neoliberal Modernity' (in this issue).

${ }^{34}$ See for instance Murray Bookchin, "Libertarian Municipalism: An Overview," Society and Nature, Vol. 1, No. 1, (1992) pp. 93-104, "The meaning of confederalism", Society and Nature, Vol. 1, No. 3, (1993) pp. 41-54 and "Communalism: The Democratic Dimension of Anarchism," Democracy and Nature (formerly Society and Nature), Vol. 3, No. 2 (1996), pp. 1-17.

35 Janet Biehl, The Politics of Social Ecology: Libertarian Municipalism, (Montreal: Black Rose Press, 1998).

${ }^{36}$ See Takis Fotopoulos, Towards An Inclusive Democracy, pp. 328-340 ; see also Takis Fotopoulos, 'Social Ecology, Eco-Communitarianism and Inclusive Democracy', Democracy \& Nature, vol 5 no 3 (November 1999), pp. 561-576.

${ }^{37}$ M. Bookchin , The Philosophy of Social Ecology, (Montreal: Black Rose, 1995) p. xii. Although Bookchin explicitly acknowledges that social evolution is profoundly different from organic evolution, still, he sees a 'directionality' towards a democratic ecological society, ibid. p. 17.

${ }^{38}$ See Takis Fotopoulos, Towards An Inclusive Democracy,pp. 328-340.

39 Janet Biehl, The Politics of Social Ecology: Libertarian Municipalism, chs 10 \& 12.
} 
${ }^{40}$ See for a proposed mechanism of allocating resources in an economic democracy, Takis Fotopoulos, Towards An Inclusive Democracy, ch 6.

${ }^{41}$ Murray Bookchin, 'Comments on the International Social Ecology Network Gathering and the 'Deep Social Ecology' of John Clark', Democracy \& Nature, vol 3, no 3 (1997) p. 185.

${ }^{42}$ See Michael Albert, ‘Assessing Libertarian Municipalism', Znet website.

43 This is obvious by statements like the following ones: 'I am not sure, for example, why libertarian municipalism feels that no means of representation can ever be designed to function compatibly with popular assemblies, preserving democracy but functioning better in situations that transcend small group concerns', ibid.

${ }^{44}$ Michael Albert and Robin Hahnel, Looking Forward: Participatory Economics for the Twenty-First Century (Boston: South End Press, 1991).

45 John Crump, "Markets, Money and Social Change", Anarchist Studies, Vol. 3, No. 1 (Spring 1995), pp. $72-73$.

${ }^{46}$ See Fotopoulos, Towards An Inclusive Democracy, pp. 253-54.

${ }^{47}$ See T. Fotopoulos, Towards An Inclusive Democracy, ch 5.

${ }^{48}$ Murray Bookchin , "Libertarian Municipalism: An Overview," Society and Nature, Vol. 1, No.1, (1992) p. 102.

${ }^{49}$ Murray Bookchin , "Communalism: The Democratic Dimension of Anarchism," Democracy and Nature (formerly Society and Nature), Vol. 3, No. 2 (1996).

${ }^{50}$ Biehl, The Politics of Social Ecology, ch 7.

51 ibid. p. 66; see also Bookchin's interview in the same book.

${ }^{52}$ Biehl, The Politics of Social Ecology, ch 7.

${ }_{53}$ Murray Bookchin, Social Anarchism or Lifestyle Anarchism, (Edinburgh: AK Press, 1995) p. 10.

54 Tom Cahill, 'Co-operatives and anarchism' in For Anarchism, ed by David Goodway, (London: Routledge, 1989, pp. 235-258.

55 John Griffin, 'Dodgy Logic and the Olympians', Total Liberty, vol 2 no 1, 1999, pp.10-11; see also my reply 'Pragmatic 'anarchism' or anarchism?" Total Liberty, vol 2 no 2, 2000, pp.6-8.

${ }^{56}$ See e.g. Richard Griffin, 'Evolution Versus Revolution,' Total Liberty, Volume 2 Number 2 (Spring 2000),pp.9-10.

${ }^{57}$ Fotopoulos, Towards An Inclusive Democracy, ch 1; see also, Fotopoulos,' The Myth of postmodernity'.

${ }^{58}$ Murray Bookchin , "Libertarian Municipalism: An Overview," p. 102.

${ }^{59}$ See Fotopoulos, Towards An Inclusive Democracy, pp. 181-183.

${ }^{60}$ David Pepper, Eco-socialism:From Deep Ecology to Social Justice (London:Routledge, 1993) p. 200.

${ }^{61}$ Takis Fotopoulos, The Limitations of Life -style Strategies, Democracy \& Nature, vol 6 no 2 (July 2000), pp. 287-308.

${ }^{62}$ See for instance Ted Trainer,' Debating the significance of the Global Eco-village Movement; A reply to Takis Fotopoulos' (in this issue).

${ }^{63}$ Ted Trainer,' Debating the significance of the Global Eco-village Movement; A reply to Takis Fotopoulos' (in this issue); see also Takis Fotopoulos,'The transition to an alternative society: the Ecovillage movement, the Simpler Way and the Inclusive Democracy project' (ibid.).

${ }^{64}$ Peter Hain, Radical Regeneration, Protest, Direct Action and Community Politics, (London: Quartet Books, 1975) p 99.

65 ibid. p. 102.

66 ibid, pp. 99-101.

${ }^{67}$ Rosa Luxemburg, The Mass Strike, The Political Party and the Trade Unions (London, Merlin Press, 1906), p.14.

${ }^{68}$ See Takis Fotopoulos, 'The End of Traditional Antisystemic Movements' and also Globalisation, the Reformist Left and the Anti-globalisation "movement".

${ }^{69}$ See Takis Fotopoulos, 'Globalisation, the Reformist Left and the Anti-globalisation "movement",

${ }^{70}$ See M.Hardt \& A. Negri, Empire, (Cambridge Mass. Harvard University Press, 2000). 
${ }^{71}$ Takis Fotopoulos, 'Globalisation, the reformist Left and the anti-globalisation movement' p. 274.

${ }^{72}$ See Fotopoulos, Towards An Inclusive Democracy, ch 8 for the case against 'scientification' or

'objectification' of the liberatory project.

73 See for a detailed description of an inclusive democracy Takis Fotopoulos, Towards An Inclusive Democracy, chs 5-6.

${ }^{74}$ See for a detailed description Takis Fotopoulos, Towards An Inclusive Democracy, ch 7. See, also, T.

Fotopoulos, 'Mass Media, Culture and Democracy, Democracy \& Nature, vol 5 no 1 (March 1999) pp. 33 -

64 and 'The limitations of Life-style strategies'.

${ }^{75}$ See Fotopoulos, The End of Traditional Antisystemic Movements.

${ }^{76}$ See T. Fotopoulos, 'Class Divisions Today-the Inclusive Democracy Approach'.

77 See e.g. Mao Tse-Tung, 'Report of an investigation of the peasant movement in Hunan' (March 1927) in

Selected Readings from the works of Mao Tse-Tung (Peking: Foreign Languages Press, 1967).

${ }^{78}$ See for instance Ernest Mandel, 'The new vanguard' in Tariq Ali's (ed) The New Revolutionaries (New York: William Morrow \&Co, 1969).

${ }^{79}$ See Fotopoulos, 'The End of Traditional Antisystemic Movements'.

${ }_{81}^{80}$ See, for instance, Anthony Giddens, The Third Way (Oxford: Polity Press, 1998).

81 See e.g. Erik Olin Wright, Classes, (London: Verso, 1985/1997) and, D.Ames Curtis, 'On the Bookchin/Biehl resignations and the creation of a new liberatory project', Democracy \& Nature, vol 5 no 1 , pp. 163-74.

${ }^{82}$ Murray Bookchin, Post-scarcity anarchism, (London: Wildwood House, 1974), p. 191.

${ }^{83}$ C. Castoriadis' introductory interview in The Castoriadis Reader, edited by David Ames Curtis, (Oxford: Blackwell, 1997) pp.26-27.

${ }^{84}$ Ellen Meiksins Wood, Democracy Against Capitalism, (Cambridge: Cambridge University Press, 1995) p. 262.

${ }^{85}$ See Anthony Giddens, The Third Way, pp. 80-81.

${ }^{86}$ See Takis Fotopoulos, Towards An Inclusive Democracy, chs 5-7 ; see also Murray Bookchin , "The Ghost of Anarcho-Syndicalism", Anarchist Studies, Vol. 1, No. 1 (Spring 1993), pp 3-24.

${ }^{87}$ A perfect example of such a formulation of the basic ID principles is given in the text prepared by the Athens group which publishes a magazine under the title 'Periektiki Dimokratia' (Inclusive Democracy); this text is repeated on every issue of the magazine.

${ }^{88}$ See T. Fotopoulos, 'The myth of postmodernity'.

${ }^{89}$ See Takis Fotopoulos, 'Outline of an economic model for an inclusive democracy', Democracy \& Nature, vol 3 no 3 (1997) pp. 21 -56; see also for further analysis, Towards An Inclusive Democracy, pp. 289-300.

${ }^{90}$ See for a description of the LETSystem, Ross V.G. Dobson, Bringing the Economy Home from the Market (Montreal: Black Rose, 1993).

91 see C. George Benello et al., Building Sustainable Communities, (New York: Bootstrap, 1989) Part I.

92 See M. A. Lutz \& K. Lux, Humanistic Economics (New York: Bootstrap, 1988), pp. 263-68.

${ }^{93}$ See ch 6, pp. 255-274

${ }^{94}$ Fotopoulos, Towards An Inclusive Democracy, pp. 213-1. 